\title{
Diet and mobility of fauna from Late Neolithic-Chalcolithic site of Perdigões, Portugal
}

\author{
I. Žalaité ${ }^{\mathrm{a}}$, A.F. Maurer ${ }^{\mathrm{a}}$, V. Grimes ${ }^{\mathrm{b}, \mathrm{c}}$, A.M. Silva ${ }^{\mathrm{d}, \mathrm{e}}$, S. Ribeiro ${ }^{\mathrm{h}}$, J.F. Santos ${ }^{\mathrm{h}}$, C. Barrocas Dias ${ }^{\mathrm{a}, \mathrm{i}, *}$,
} A.C. Valera ${ }^{\mathrm{f}, \mathrm{g}, * *}$

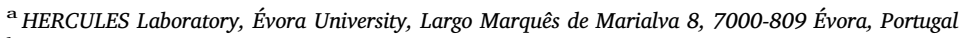

${ }^{\mathrm{b}}$ Department of Archaeology, Memorial University, St. John's, NL A1C 5S7, Canada

${ }^{\mathrm{c}}$ Department of Earth Sciences, Memorial University, St. John's, NL A1C 5S7, Canada

d Laboratory of Prehistory, CIAS, Department of Life Sciences, University of Coimbra, 3000-456 Coimbra, Portugal

e UNIARQ, University of Lisbon, Portugal

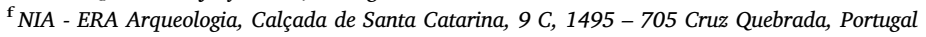

${ }^{\mathrm{g}}$ ICArEHB-Universidade do Algarve, Campus Gambelas, 8005-139 Faro, Portugal

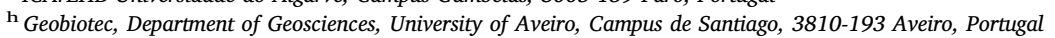

${ }^{i}$ School of Sciences and Technology, Chemistry Department, Rua Romão Ramalho 59, Évora, Portugal

\section{A R T I C L E I N F O}

\section{Keywords:}

Diet

Mobility

Faunal stable isotope analysis

Neolithic-Chalcolithic

Portugal

\begin{abstract}
A B S T R A C T
Perdigões is located in the Alentejo region of south-eastern Portugal, with occupational phases dating from the Late Middle Neolithic to Late Chalcolithic/Early Bronze Age (middle 4th and 3rd millennium BCE) periods. It is a complex site that can be considered as a centre of social aggregation and a part of a larger settlement network. In this study, the nature of animal subsistence patterns as well as husbandry management practices and mobility are examined using stable carbon and nitrogen isotopic values from bone collagen of 35 archaeological faunal samples (Canis familiaris, Bos taurus, Bos primigenius, Sus sp., Ovis/Capra, Cervus elaphus, O. cuniculus, Equus sp.) and strontium isotope $\left({ }^{87} \mathrm{Sr} /{ }^{86} \mathrm{Sr}\right)$ analysis of 23 enamel samples. To provide necessary biological ${ }^{87} \mathrm{Sr} /{ }^{86} \mathrm{Sr}$ baseline data, the strontium isotopic composition of 14 modern plant samples were measured. The stable carbon and nitrogen isotope data shows that animals subsisted on a selection of $\mathrm{C}_{3}$ terrestrial resources, with subtle differences in animal husbandry practices in domesticated animals, while strontium isotope analysis shows that $<5 \%$ of analysed fauna is consistent with the local bioavailable strontium isotopic range. Other animals can be divided into two clusters - those having strontium isotope values either lower or higher than the bioavailable range, showing that most of the fauna browsed and grazed within $10 \mathrm{~km}$ of the site's surrounding landscape, which is not such an unusual practice during prehistoric times.
\end{abstract}

\section{Introduction}

Perdigões is a Neolithic-Early Bronze Age (3500-2000 BCE) site with a long continuous period of occupation, and a significant archaeological importance for addressing the development of social complexity due to its size, time span, diversity of practices (primarily funerary practices) and richness in archaeological assemblages. Perdigões has been studied for almost 20 years, and several publications have been made on different topics (i.e., palaeoenvironmental reconstruction, general synthesis of the site, anthropological and material studies) (Valera et al., 2014a, 2014b). More research is required, however, on the reconstruction of human and animal dietary and mobility patterns since Perdigões could have been an important centre of social aggregation in southwest Iberia (Valera, 2015a).

Stable and radiogenic isotope analysis of teeth and bone has become an established method in historical and archaeological studies to document changes in diet, mobility, residency patterns and exploitation strategies (Fontanals-Coll et al., 2016; Knipper et al., 2013; Saragoça et al., 2016; Al-Shorman and El-Khouri, 2011). This is all due to the principle that ingested food and water leave a chemical 'fingerprint' in body tissues that reflect different components of the diet and the biogeochemical environment in which they are formed (Ambrose, 1993; Bentley, 2006). These studies are usually focused on human skeletons, while faunal remains receive relatively less attention (Guiry, 2012; Reitsema et al., 2013; Müldner et al., 2014; Guiry et al., 2016a, 2016b). Faunal bone studies are mainly used for providing the ecological

\footnotetext{
* Correspondence to: C. Barrocas Dias, HERCULES Laboratory, Évora University, Largo Marquês de Marialva 8, 7000-809 Évora, Portugal.

** Correspondence to: A.C. Valera, NIA - ERA Arqueologia, Calçada de Santa Catarina, 9 C, 1495 - 705 Cruz Quebrada, Portugal.

E-mail addresses: cmbd@uevora.pt (C. Barrocas Dias), antoniovalera@era-arqueologia.pt (A.C. Valera).
} 

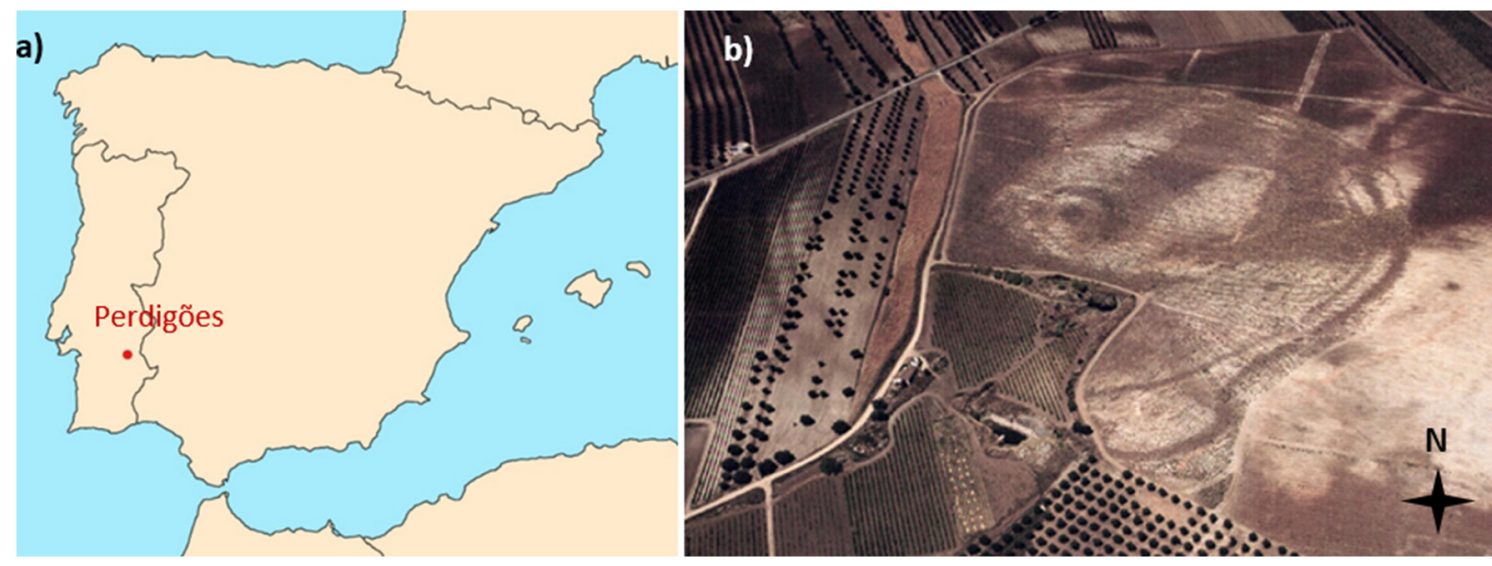

Fig. 1. The site of Perdigões: 1a) geographical location; 1b) aerial photo of the site.

baseline required for understanding and interpreting stable isotope values in associated humans. However, the analysis of faunal skeletons provides an inside view into the relations between animals and humans, enabling the identification of animal management choices and husbandry strategies of prehistoric herders, and the reconstruction of the movements and migratory habits of wild and domestic fauna (Bogaard et al., 2007).

In this study stable isotopes of carbon and nitrogen recorded in bone collagen were used to reconstruct prehistoric faunal nutritional behaviour and to assess evidence for possible changes in animal diet through time that may point to differences in animal management and herding strategies from the Perdigões site. Additionally, strontium isotope analysis of modern plants collected from the surroundings of the Perdigões site were measured to establish the local strontium isotope background which is used to interpret strontium isotope values from faunal tooth enamel, as witness of their movements and for further exploration of the mobility pattern of the human population buried at Perdigões.

\subsection{Stable isotope analysis}

Since bone is built up from the food an animal consumes it encloses information about its diet. The isotopic composition of bone collagen reflects the protein portion of the diet, while the isotopic composition of the mineral part of bone and teeth (bioapatite) mirrors the composition of dietary proteins, carbohydrates and lipids (van der Merwe, 1992; Lee-Thorp et al., 1989). Bone diagenesis leads to some level of uncertainty in the stable isotopic ratios measured in bone apatite, resulting in the frequent use of the isotopic composition of collagen as a proxy for ancient diet reconstruction.

Carbon and nitrogen isotope values, expressed as $\delta^{13} \mathrm{C}$ and $\delta^{15} \mathrm{~N}$, represent the ratios of the heavier to lighter isotopes $\left({ }^{13} \mathrm{C} /{ }^{12} \mathrm{C}\right.$ and ${ }^{15} \mathrm{~N} /{ }^{14} \mathrm{~N}$ ) in a sample compared to international standards (PDB for carbon and AIR for nitrogen). The ratios are expressed in parts per thousand, or per mil \%o units. Bone collagen $\delta^{13} \mathrm{C}$ values distinguish between dietary components such as $\mathrm{C}_{3}$ and $\mathrm{C}_{4}$ photosynthetic plants and the animals that consume them (van der Merwe, 1992; Ambrose, 1993), and can indicate an amount of marine or freshwater protein in the diet as compared to terrestrial proteins (Pate, 1994; De Niro and Epstein, 1978). The movement of carbon through the food chain (from plant to consumer) results in average trophic level shifts of approximately 5\%o between plants and collagen values from herbivores, and only around $1-2.5 \%$ between collagen from herbivore to carnivore (De Niro and Epstein, 1978; Bocherens and Drucker, 2003). Bone collagen nitrogen isotopic ratios $\left(\delta^{15} \mathrm{~N}\right)$ are useful to infer the trophic level of an organism. Between trophic levels, the fractionation of nitrogen isotope leads to an enrichment in $\delta^{15} \mathrm{~N}$ values of approximately $3 \%$ from diet to body tissues. Though, there are some debate on this topic, as in some large-scale ecological studies a value of $3-4 \%$ is used to show an increase in trophic level, while some small-scale animal feeding experiments yield values between 1.5\%o to 6\%o (Hedges and Reynard, 2007; Bocherens and Drucker, 2003; O'Connell et al., 2012). $\Delta{ }^{15} \mathrm{~N}_{\text {diet-collagen }}$ offset must be interpreted with caution as not to overestimate the importance of different types of food. In this study, we use a value of $3 \pm 1 \%$, which mostly fits with numerous predator-prey relationships in terrestrial ecological situations.

In archaeology, strontium isotopes $\left({ }^{87} \mathrm{Sr} /{ }^{86} \mathrm{Sr}\right)$ can be used to identify migrants and to examine movements of individuals, based on the strontium isotope baseline within the surroundings of the site studied. A common procedure to determine the local strontium isotopic composition is the study of ${ }^{87} \mathrm{Sr} /{ }^{86} \mathrm{Sr}$ of local fauna (Price et al., 2002). However, the use of domestic animals as indicative of the local range has been a subject of debate because animals can have movement patterns similarly as humans (Maurer et al., 2012). Therefore, in this study modern plant samples were collected from various geological substrates nearby Perdigões and used to characterize the so-called local ${ }^{87} \mathrm{Sr} /{ }^{86} \mathrm{Sr}$ signal. Unlike carbon and nitrogen stable isotopes recorded in bone collagen, strontium isotopes in enamel are not substantially fractionated and do not undergo remodeling processes. Therefore, ${ }^{87} \mathrm{Sr} /{ }^{86} \mathrm{Sr}$ archived in tooth enamel reflects the bioavailable strontium isotope values from the region where an individual lived when enamel mineralization took place (Bentley, 2006). However, by using strontium isotopes, it is impossible to identify individuals who moved from locations with similar geological features.

\section{Perdigões archaeological site}

Perdigões is located in Reguengos de Monsaraz near Guadiana River, Évora district, in the Alentejo hinterland, South Portugal (Fig. 1). It was occupied from Late Middle Neolithic to Late Chalcolithic/transition to the Bronze Age (3500 BCE-2000 BCE) period with a progressive complexity throughout its existence. It is comprised of a set of ditched enclosures with 15 roughly concentric ditches defining $>10$ enclosures in a natural theatre, consisting in an inclined circular basin open to the East, like a natural theatre (Valera et al., 2014a, 2014b). The archaeological record of the Perdigões complex gives a complete story of its development and trajectory over the time span of a thousand and a half years.

The site was founded in the Late Middle Neolithic (3500-3400 BCE) with smaller enclosures in the centre of the natural theatre and a Neolithic cromlech in the Eastern side. During the Late Neolithic (3300-2900 BCE) the site progressively grew in complexity and in the Chalcolithic period (2900-2500 BCE) shows an intense and diversified increment of funerary practices and construction of several roughly concentric ditched enclosures, reaching its peak in the Late Chalcolithic (2500-2200 BCE). During all the construction periods the site has 
maintained its astronomic and ideological principles - both the Neolithic cromlech and a Chalcolithic necropolises are located to the east side, the eastern gates are aligned with winter and summer solstices, while the western gates are aligned to the corresponding sunsets, allowing the horizon of the site to function as an annual calendar (Valera, 2012; Valera et al., 2014a, 2014b; Valera, 2015a). The Perdigões enclosure is thus a huge and complex site that developed continuously and coherently. It played a very important social role on the local and regional scale regarding the structure of the local settlement network, that occupied the granite area of the Ribeira de Vale do Álamo valley, and the regional and inter-regional networks of interaction.

\subsection{Animal management practices}

In this context, the approach to animal management practices and mobility is particularly important in characterizing the social and economic bases of the communities that attended Perdigões and also of the nature of sites and social practices that were taking place there, as well as the importance of animal mobility in a global scenario.

The study of the fauna done by Cordeiro da Costa (2013) shows a progressive increase in the domestic species with a decrease in wild species, which is particularly noticeable during the middle/third quarter of the 3rd millennium BCE. Faunal remains from ditches and pits reveal an important presence of Sus, Ovis-capris and Bos species documenting an important point of pastoralism and animal management practices (Costa, 2010; Cabaço, 2012, 2010). It is difficult to distinguish wild Sus sp. from the domestic one, but the larger numbers of Sus sp. in the site suggests that the majority of the osteological remains are likely from the domesticated species, which is consistent with all the available data of studied faunal collections from the Alentejo region (Valente and Carvalho, 2014). Other important domestic species consist of sheep/goat, cattle, alongside dog. The most abundant wild species found in the site is red deer, followed by equids - presenting itself a set of question whether they were domesticated or not (Valera, 2015b).

However, the faunal collection of Perdigões site has been only partially studied (Cabaço, 2012; Costa, 2010). Therefore, at the moment any comparison between the Neolithic and Chalcolithic fauna at Perdigões site cannot be fully discussed, especially because most of the fauna which has been already studied comes from the Chalcolithic period, while the Late Neolithic fauna is currently being studied. However, the faunal studies already completed show, after an initial period (3500-3300 BCE) where the representation of hunted species is equivalent or slightly higher, a predominant consumption of domestic animals throughout the Late Neolithic (3300-2900 BCE) and Chalcolithic (2900-2200 BCE), raising questions regarding management practices and mobility of domestic animals. To address those questions, stable isotopic analysis, in particular carbon, nitrogen and strontium are of significant heuristic potential, especially when combined with the results of archaeozoological studies.

\subsection{Geological, paleoenvironmental and local context}

The studied area (near Reguengos de Monsaraz) is in the southern Alentejo region and bounded by the Tejo River in the north, Guadiana River and Spanish border in the east, Caldeirão mountain range in the south and North Atlantic Ocean in the west (Valente and Carvalho, 2014).

Geologically, the region of Reguengos de Monsaraz belongs to the Ossa Morena Zone, which has the oldest rocks from the middle-upper Cambrian, while other lithological units range from the Lower Ordovician up to Lower Devonian sedimentary sequences (Fig. 2). It is mainly composed of heterogeneous lithology including tonalites and granodiorites (dominant) and the internal area of the massif is composed of gabbro-dioritic rocks (Antunes et al., 2010).

The site of Perdigões is situated north-northwest of Reguengos de
Monsaraz, in an elongated inclined natural basin, between 226 and $252 \mathrm{~m}$ in height, with a gabbro-dioritic substrate. Due to its natural geomorphological nature, the site presents important underground water reserves. The peneplain surrounding the site and extending to East (Fig. 3) is composed by granitoid rocks. They have phaneritic texture and have plagioclase, hornblende and quartz as additional minerals (Reis, 1998). In this granodioritic area, that corresponds to the Ribeira do Álamo valley, more than a hundred megalithic monuments are located and the majority of the known settlements from the Late Neolithic and Chalcolithic are situated; they constitute what we call the local settlement network. This area is surrounded by schists, occurring at distances larger than $5 \mathrm{~km}$ from Perdigões at North, West and South and $10 \mathrm{~km}$ at East.

The area north-east from Perdigões (Motrinos, Serra das Pedras) is mostly composed of siliceous shales, while north and south-east (Arraieiras) overlaps with the passage of granitoid rocks to the schists (predominantly pelitic) of the Barrancos Formation (Carvalhosa and Zbyszewski, 1991).

While recent palaeoenvironmental analyses of archaeological deposits by Danielsen and Mendes (2013) and Wheeler (2010) showed poor taphonomic conditions, data obtained from one pit and three ditches attributed to Late Neolithic period, indicates that dominant plant taxa consisted of Quercus sp. (Oak) with more modest contributions of Ulmus sp. (Elm) and Alnus sp. (Alder). The shrub species are represented by the Corylus avellana (Hazel), Oleaceae (Olive) and Ericaceae (Heather family). The herbaceous species were dominated by Poaceae (grasses) which can be ascribed to temperate and humid climate with a relatively open park-like environment. Data from microcharcoals show phases of burning (Wheeler, 2010; Danielsen and Mendes, 2013). Cerealia pollen, although present, is extremely rare.

Data obtained from a ditch of the Chalcolithic Period shows that the dominant species is still Quercus with lesser amounts of Ulmus and Corylus-avellana, while the presence of Typhaceae (family of reeds) points to even more humid conditions. Increase in Poaceae indicates a more open landscape, where trees and bushes are scattered around (Danielsen and Mendes, 2013). These data suggest an open Mediterranean shrub landscape represented by the plants that grew more or less locally in the region at that time. With the transition from Late Neolithic to Chalcolithic began a new phase in which anthropogenetic deforestation led to some changes in the landscape, which is in agreement with the archaeological data of Perdigões site growth during the Chalcolithic (Valera et al., 2014a, 2014b).

\section{Materials and methods}

\subsection{Archaeological faunal and modern plant samples}

Faunal specimens for this study were collected from a very large assemblage of thousands of specimens, which themselves represent only a small part of the faunal remains buried at Perdigões. They were recovered during excavations carried between 2007 and 2016. The assemblage consists of 6 samples of domestic cattle (Bos taurus), 2 aurochs (Bos primigenius), 3 horses (Equus sp.), 7 red deer (Cervus elaphus), 10 ovicaprines (Ovis/Capra), 12 pigs (Sus sp.), 1 rabbit (O. cuniculus) and 5 dogs (Canis familiaris) from Neolithic and Chalcolithic periods from different archaeological contexts (Table 1): Pits 48, 49, 82 and Ditch 13 from late Middle Neolithic (3500-3300 BCE); Pits 13, 14, Hypogeum 1 and Ditch 12 from Late Neolithic (3300-2900 BCE); Pits 45, 54 and Ditches 2, 3, 4, 7 from Chalcolithic (2800-2200 BCE). Samples did not exhibit any human induced changes, like cut marks, fractures or any other evidence of consumption.

To determine the local bioavailable ${ }^{87} \mathrm{Sr} /{ }^{86} \mathrm{Sr}$ values near the Perdigões site, 14 modern vegetation samples were collected from uncultivated areas in a $\sim 10-\mathrm{km}$ radius around the Perdigões enclosure during field work in September 2016. The geographical coordinates for the plant sample collection points can be found in Table 2, while Fig. 3 


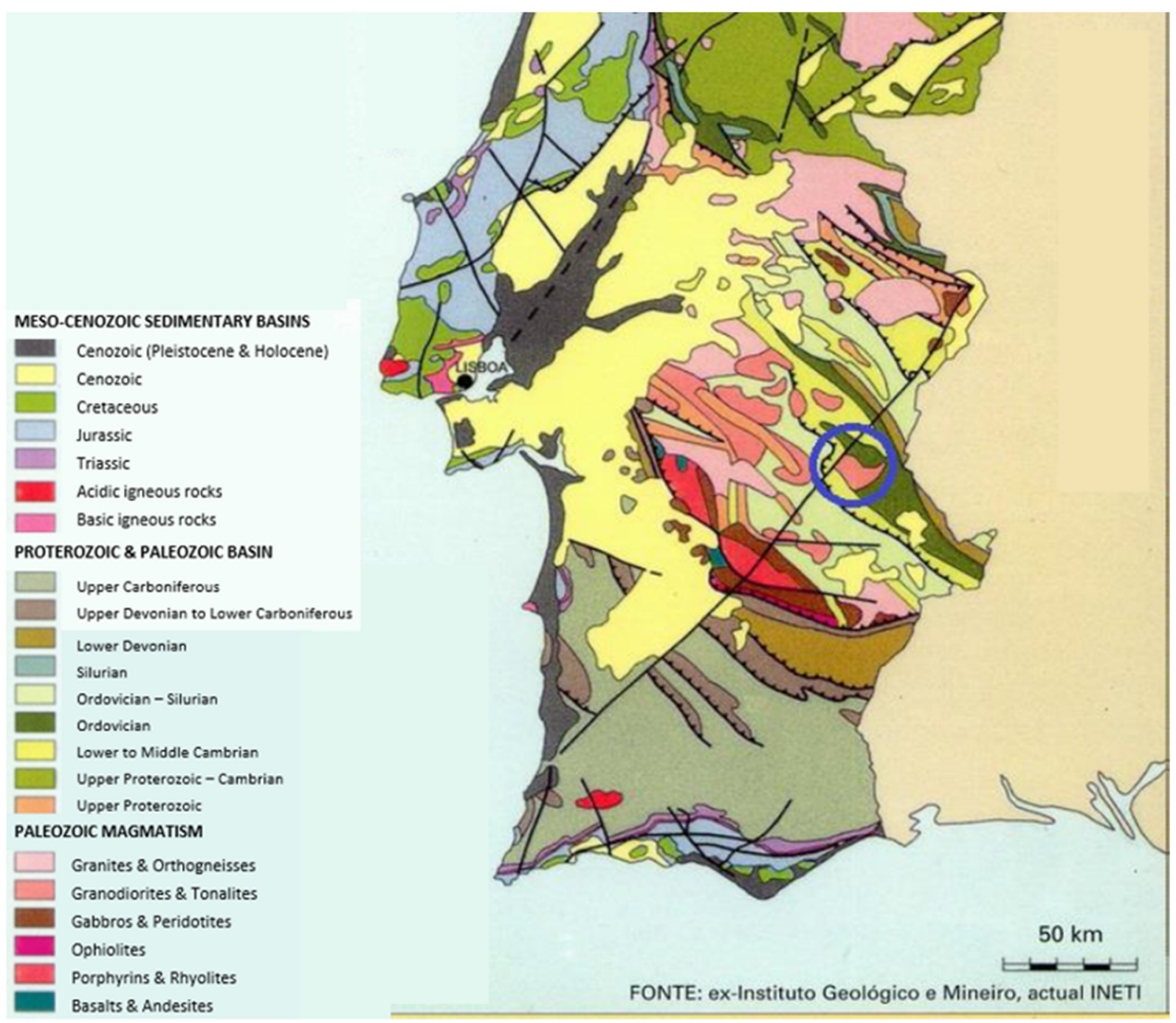

Fig. 2. Geological map of Portugal (blue circle corresponds to the location of Reguengos de Monsaraz). (For interpretation of the references to color in this figure legend, the reader is referred to the web version of this article.)

presents their approximate location within the geological map of the Perdigões area. After collection, the plant leaves were thoroughly washed with Milli-Q water, dried under cover in an oven at $50^{\circ} \mathrm{C}$ overnight, hand-crushed, and stored in a desiccator until analysis.

\subsection{Bone collagen extraction and analysis}

Sample preparation and analysis was done at the HERCULES Laboratory, at the University of Évora, Portugal. Compact bone from mandibles $(n=26)$ when available, or from other bones (1 iliac, 1 metatarsal phalanx, 1 neck vertebrae, 2 femurs, 1 metapodial bone, 2 metacarpal bones and one 1st phalanx) (see Table 1) was sampled for collagen extraction. Approximately $500 \mathrm{mg}$ of compact bone were mechanically cleaned using a handheld drill with a diamond-coated burr to remove surface contaminants such as soil or dust.

Collagen was extracted from the bone samples for stable carbon and nitrogen isotope analysis following protocols established by Longin (1971) with some modifications (Britton et al., 2008; Knipper et al., 2013).

The bone samples were demineralised in $10 \mathrm{ml}$ of $0.5 \mathrm{M}$ hydrochloric acid $(\mathrm{HCl})$. They were regularly vortexed and left to sit for several hours at room temperature and refrigerated $\left(4^{\circ} \mathrm{C}\right)$ overnight. This process was repeated each day with a weekly acid change until the bone took on a soft consistency (about two weeks).
Samples were then repeatedly rinsed in Milli-Q water, vortexed and centrifuged at $5000 \mathrm{rpm}$ for $5 \mathrm{~min}$ until the solution reached neutral $\mathrm{pH}$. Following this, around $10 \mathrm{ml}$ of $0.125 \mathrm{M}$ of sodium hydroxide $(\mathrm{NaOH})$ was added to each tube and left to sit for $20 \mathrm{~h}$ at room temperature in order to remove humic acids and non-collagenous organic residues. Following this, collagen pseudomorphs received multiple rinses of Milli-Q water, centrifuged at $5000 \mathrm{rpm}$ for $5 \mathrm{~min}$ between rinses, until a neutral $\mathrm{pH}$ of the solution was obtained.

The tubes were then filled with $\sim 10 \mathrm{ml}$ of $0.01 \mathrm{M} \mathrm{HCl}$ and put in a drying oven at $70^{\circ} \mathrm{C}$ for $48 \mathrm{~h}$ to gelatinize. Sample solutions were filtered using Ezee-Filter ${ }^{\mathrm{TM}}$ separators (Elkay) to remove any insoluble residues. Finally, collagen samples frozen in liquid nitrogen were freeze-dried for $48 \mathrm{~h}$.

Subsamples of collagen were weighted into tin capsules and combusted into $\mathrm{CO}_{2}$ and $\mathrm{N}_{2}$ in an elemental analyser (EA Flash $2000 \mathrm{HT}$, Thermo Fisher Scientific). Isotopic ratios of $\delta^{13} \mathrm{C}$ and $\delta^{15} \mathrm{~N}$ were obtained on a Delta V Advantage isotope ratio mass spectrometer (Thermo Fisher Scientific).

The raw data were normalized by two-point calibration using international reference materials, such as IAEA-CH-6 (sucrose, $\delta^{13} \mathrm{C}=-10.499 \%$ ),$\quad$ IAEA-600 (caffeine, $\quad \delta^{13} \mathrm{C}=-27.771 \%$; $\delta^{15} \mathrm{~N}=+1.0 \%$ ) and IAEA-N-2 (ammonium sulphate, $\delta^{15} \mathrm{~N}=+20.3 \%$ ) for carbon and nitrogen isotopic composition. The $\delta^{13} \mathrm{C}$ and $\delta^{15} \mathrm{~N}$ values are expressed in units per mill (\%o) relative to 


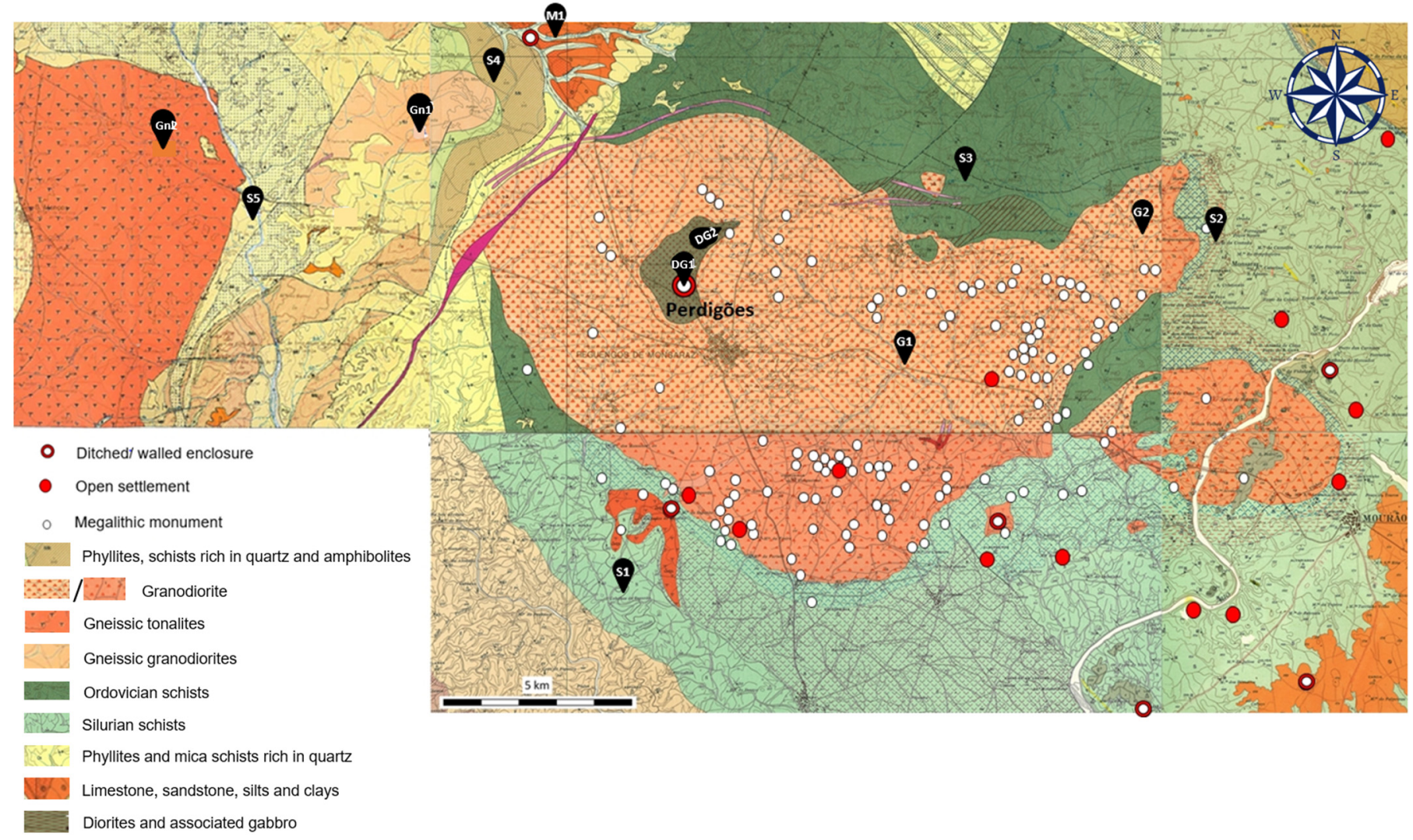

Fig. 3. Geological map of the area of the Perdigões site and geographical location where modern plants were collected. Location of Megalithic monuments, open settlements, as well as ditched enclosures found in the surroundings of Perdigões are also provided.

VPDB and AIR, with analytical precision of $0.2 \%$ and $0.3 \%$, respectively. A calibrated in-house standard (L-alanine, $\delta^{13} \mathrm{C}=-19.17 \%$; $\delta^{15} \mathrm{~N}=+4.36 \%$ ) was measured at regular intervals throughout analytical sequences (every ten analyses) to check and correct for any instrumental drift. The elemental $(\mathrm{C} \%, \mathrm{~N} \%, \mathrm{C} / \mathrm{N})$ and isotopic composition of analysed collagen samples are reported in Table 1.

\subsection{Strontium isotope: preparation and analysis}

Strontium isotopic analyses were performed on faunal tooth enamel of 23 individuals ( 15 belonged to fauna from Chalcolithic period and 8 from Neolithic period). The majority of analysis (14 enamel and all plant samples) were done at the Laboratory of Isotope Geology of the University of Aveiro, Portugal (LGI-UA), with 9 enamel samples analysed at the Memorial Applied Archaeological Sciences Laboratory (MAAS) and CREAIT facilities of Memorial University of Newfoundland (St John's, Canada).

For the samples analysed in LGI-UA, around $20 \mathrm{mg}$ of enamel were collected using a drill with a diamond bit from the tooth in a lengthwise fashion from the crown tip to root in order to incorporate enamel from the entire time of crown formation. Samples were pre-treated with $1 \mathrm{M}$ $\mathrm{Li}$ acetate-acetic acid for $12 \mathrm{~h}$ to remove any secondary carbonates that might have introduced diagenetic strontium (Hoppe et al., 2003). Samples were then rinsed with Milli-Q water, vortexed and centrifuged for $5 \mathrm{~min}$ at $5000 \mathrm{rpm}$ for four times or until the $\mathrm{pH}$ was neutral. Afterwards, they were dried overnight in the oven at $70^{\circ} \mathrm{C}$. The complete pre-treatment led to some sample loss.

For the plant analysis, around 1-1.2 $\mathrm{g}$ of the dried and crushed plant material was placed into acid-cleaned ceramic crucibles and ashed in a muffle furnace at $550^{\circ} \mathrm{C}$ for $12 \mathrm{~h}$. Plant samples and faunal dental enamel were digested using Suprapur ${ }^{\circledast}$ reagents, strontium extracted and analysed under clean laboratory conditions. The laboratory procedure used ion exchange chromatography and Teflon-distilled reagents to isolate strontium prior to instrumental analysis. All samples were digested using Suprapur ${ }^{\circledR}$ nitric acid (with the additional step of digesting with $\mathrm{H}_{2} \mathrm{O}_{2}$ for plant samples) and evaporated to dryness. Sr-Resin (50-100 $\mu \mathrm{m}$, Eichron) was used for separating strontium from isobaric interferences. Samples were further loaded onto single tantalum filaments with a drop of phosphoric acid $\left(\mathrm{H}_{3} \mathrm{PO}_{4}\right)$ and measured with a VG Sector 54 multi-collector thermal ionization mass spectrometer in a dynamic mode. The standard reference material NIST SRM 987 was concomitantly measured and provided a value of $0.710256 \pm 15$ (conf. limit 95\%, $\mathrm{N}=13$ ) for faunal samples and $0.710267 \pm 14$ (conf. limit $95 \%, \mathrm{~N}=13$ ) for plant samples. Strontium procedural blanks were $<400 \mathrm{pg} \mathrm{Sr}$, giving a secure working interval.

For the enamel samples prepared in the Memorial Applied Archaeological Sciences Laboratory, the extraction and purification methodologies are described elsewhere (Madgwick et al., 2017). At the Memorial University of Newfoundland, strontium isotope ratios were measured using a Thermo Finnigan Neptune multicollector inductively coupled mass spectrometer (MC-ICP-MS) in the CREAIT facility. All data were first corrected for mass bias using the ${ }^{88} \mathrm{Sr} /{ }^{86} \mathrm{Sr}$ value of 8.375209, followed by Kryton ( $\mathrm{Kr}$ ) interference corrections using ${ }^{82} \mathrm{Kr} /{ }^{83} \mathrm{Kr}$. The final correction of all sample values was made against the strontium carbonate standard, SRM987, using an accepted value of 0.71024 (Copeland et al., 2008), which typically resulted in an ${ }^{87} \mathrm{Sr} /{ }^{86} \mathrm{Sr}$ adjustment of 0.000052 to all sample values. Total procedural blanks are typically $<1 \%$ of typical sample ${ }^{88} \mathrm{Sr}$ voltages, and measurement of ${ }^{87} \mathrm{Sr} /{ }^{86} \mathrm{Sr}$ in NIST SRM 1400 (bone ash) gave a corrected ${ }^{87} \mathrm{Sr} /{ }^{86} \mathrm{Sr}$ value of 0.71310 . 
Table 1

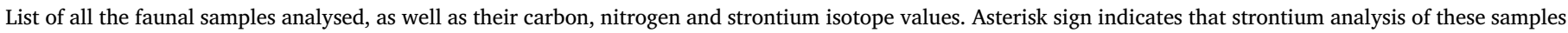

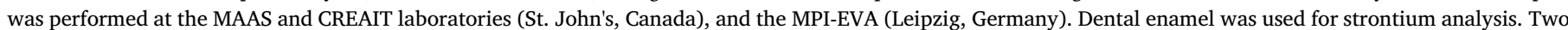

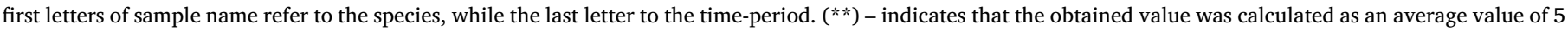

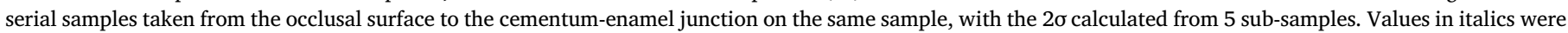
not considered in dietary discussion.

\begin{tabular}{|c|c|c|c|c|c|c|c|c|c|c|}
\hline Period/structure & Specie & Skeletal element & Sample name & $\% \mathrm{C}$ & $\% \mathrm{~N}$ & $\mathrm{C} / \mathrm{N}$ & $\delta^{13} \mathrm{C}, \%$ & $\delta^{15} \mathrm{~N}, \%$ & ${ }^{87} \mathrm{Sr} /{ }^{86} \mathrm{Sr}$ & $2 \sigma$ \\
\hline Mid Neolithic ditch 13 & Bos taurus & 1st phalanx & BtN1 & 40.4 & 14.4 & 3.3 & -20.6 & 6.9 & & \\
\hline Mid Neolithic pit 48 & Bos taurus & Mandible/tooth & BtN2 & 41.5 & 14.1 & 3.4 & -20.2 & 6.2 & 0.711974 & 0.000019 \\
\hline Mid Neolithic pit 49 & Bos taurus & Neck vertebrae & BtN3 & 41.2 & 13.9 & 3.5 & -20.5 & 5.8 & & \\
\hline Late Neolithic hypogeum 1 & Bos taurus & Tooth & BtN4 & & & & & & 0.716078 & 0.000024 \\
\hline Chalcolithic [340] & Bos taurus & Mandible/tooth & $\mathrm{BtC1}$ & 41.5 & 14.7 & 3.3 & -19.9 & 6.2 & 0.715251 & 0.000020 \\
\hline Chalcolithic ditch 7 & Bos taurus & Maxilla & $\mathrm{BtC2}$ & 31.7 & 10.9 & 3.4 & -14.7 & 8.6 & & \\
\hline Late Neolithic pit 13 & Bos primigenius & Long bone & BpN1 & 40.2 & 13.6 & 3.4 & -20.1 & 6.4 & & \\
\hline Mid Neolithic pit 48 & Bos primigenius & Long bone & BpN2 & 42.1 & 14.3 & 3.4 & -20.3 & 6.6 & & \\
\hline Mid Neolithic pit 49 & Equus caballus & Metacarpal bone & EcN1 & 39.4 & 13.1 & 3.5 & -20.8 & 5.6 & & \\
\hline Mid Neolithic pit 49 & Equus caballus & Metatarsal bone & EcN2 & 40.7 & 13.9 & 3.4 & -20.5 & 4.2 & & \\
\hline Chalcolithic pit 45 & Equus sp. & Metacarpal bone & EsC1 & 41.5 & 14.8 & 3.3 & -21.4 & 5.4 & & \\
\hline Mid Neolithic pit 49 & Cervus elaphus & Mandible/tooth & CeN1 & 38.6 & 12.9 & 3.5 & -20.5 & 5.8 & 0.715000 & 0.000020 \\
\hline Late Neolithic hypogeum & Cervus elaphus & Maxilla/tooth & CeN2 & 41.7 & 14.1 & 3.4 & -19 & 7.7 & 0.716098 & 0.000017 \\
\hline Chalcolithic ditch 7 & Cervus elaphus & Mandible & $\mathrm{CeC} 1$ & 33.8 & 12.1 & 3.3 & -19.9 & 4.8 & & \\
\hline Chalcolithic ditch 7 & Cervus elaphus & Metapodial bone & $\mathrm{CeC} 2$ & 41.2 & 14.6 & 3.3 & -19.9 & 4.4 & & \\
\hline Chalcolithic pit 54 & Cervus elaphus & Mandible/tooth & $\mathrm{CeC} 3$ & 28.6 & 9.9 & 3.4 & -19.5 & 4.4 & 0.716192 & 0.000020 \\
\hline Chalcolithic ditch 4 & Cervus elaphus & Tooth & $\mathrm{CeC} 4 *$ & & & & & & 0.717240 & 0.000011 \\
\hline Chalcolithic ditch 4 & Cervus elaphus & Tooth & CeC5* & & & & & & 0.716466 & 0.000012 \\
\hline Mid Neolithic pit 82 & Ovis/Capra & Mandible & $\mathrm{O} / \mathrm{cN} 1$ & 41.7 & 14.9 & 3.3 & -20.1 & 4.8 & & \\
\hline Late Neolithic hypogeum & Ovis/Capra & Maxilla/tooth & $\mathrm{O} / \mathrm{cN} 2$ & 41.7 & 14.3 & 3.4 & -19.9 & 5.1 & 0.714810 & 0.000024 \\
\hline Late Neolithic hypogeum & Ovis/Capra & Maxilla/tooth & $\mathrm{O} / \mathrm{cN} 3$ & 42.1 & 14.4 & 3.4 & -19.9 & 3.3 & 0.714203 & 0.000024 \\
\hline Late Neolithic hypogeum & Ovis/Capra & Mandible & $\mathrm{O} / \mathrm{cN} 4$ & 41.8 & 14.2 & 3.4 & -20.8 & 5.7 & & \\
\hline Chalcolithic ditch 2 & Ovis/Capra & Mandible & $\mathrm{O} / \mathrm{cC} 1$ & 28.0 & 10.1 & 3.2 & -20.4 & 6.7 & & \\
\hline Chalcolithic ditch 7 & Ovis/Capra & Mandible/tooth & $\mathrm{O} / \mathrm{cC} 2$ & 13.1 & 4.5 & 3.4 & -20.2 & 4.4 & 0.715374 & 0.000023 \\
\hline Chalcolithic ditch 3 & Ovis/Capra & Tooth & $\mathrm{O} / \mathrm{cC}^{*}$ & & & & & & 0.714922 & 0.000012 \\
\hline Chalcolithic ditch 3 & Ovis/Capra & Tooth & $\mathrm{O} / \mathrm{cC} 4 *$ & & & & & & 0.714435 & 0.000014 \\
\hline Chalcolithic ditch 4 & Ovis/Capra & Tooth & $\mathrm{O} / \mathrm{cC} 5^{*}$ & & & & & & 0.715780 & 0.000015 \\
\hline Chalcolithic ditch 4 & Ovis/Capra & Tooth & $\mathrm{O} / \mathrm{cC}^{*}$ & & & & & & $0.712868^{* *}$ & $0.000013^{* *}$ \\
\hline Late Neolithic hypogeum & Sus sp. & Mandible/tooth & SN1 & 40.1 & 13.5 & 3.5 & -19.4 & 5.6 & 0.712111 & 0.000021 \\
\hline Late Neolithic hypogeum & Sus sp. & Mandible/tooth & SN2 & 42.6 & 14.5 & 3.4 & -19.8 & 6.3 & 0.713091 & 0.000021 \\
\hline Late Neolithic hypogeum & Sus sp. & Maxilla & SN3 & 41.7 & 14.2 & 3.4 & -20 & 4.7 & & \\
\hline Late Neolithic pit 14 & Sus sp. & Mandible & SN4 & 42.7 & 12.3 & 4.1 & -21.1 & 5.5 & & \\
\hline Chalcolithic ditch 7 & Sus sp. & Mandible & SC1 & 36.8 & 13.2 & 3.3 & -20.1 & 5.2 & & \\
\hline Chalcolithic ditch 7 & Sus sp. & Maxilla & SC2 & 38.7 & 13.7 & 3.3 & -20.1 & 6.3 & & \\
\hline Chalcolithic ditch 2 & Sus sp. & Mandible & SC3 & 35.7 & 12.7 & 3.3 & -20.7 & 7.0 & & \\
\hline Chalcolithic pit 45 & Sus sp. & Mandible & SC4 & 40.2 & 14.4 & 3.2 & -19.8 & 7.8 & & \\
\hline Chalcolithic ditch 7 & Sus sp. & 2nd molar & SC5 & & & & & & 0.714832 & 0.000023 \\
\hline Chalcolithic ditch 3 & Sus sp. & Tooth & SC6* & & & & & & 0.716492 & 0.000019 \\
\hline Chalcolithic ditch 3 & Sus sp. & Tooth & SC7* & & & & & & 0.717146 & 0.000011 \\
\hline Chalcolithic ditch 3 & Sus sp. & Tooth & SC8* & & & & & & 0.716938 & 0.000019 \\
\hline Chalcolithic ditch 7 & O. cuniculus & Iliac & OcC1 & 41.2 & 14.7 & 3.3 & -21.9 & 3.7 & & \\
\hline Late Neolithic ditch 12 & Canis familiaris & Maxilla & CfN1 & 33.4 & 12.1 & 3.2 & -19.3 & 9.8 & & \\
\hline Chalcolithic ditch 2 & Canis familiaris & Mandible & CfC1 & 0.9 & 3.8 & 6.5 & -19.8 & 10.0 & & \\
\hline Chalcolithic pit 45 & Canis familiaris & Mandible/tooth & $\mathrm{CfC} 2$ & 25.2 & 8.9 & 3.3 & -20.4 & 7.5 & 0.716339 & 0.000017 \\
\hline Chalcolithic ditch 7 & Canis familiaris & Mandible/tooth & $\mathrm{CfC} 3$ & 15.0 & 5.3 & 3.3 & -19.2 & 9.1 & 0.711062 & 0.000020 \\
\hline Chalcolithic ditch 7 & Canis familiaris & Mandible & $\mathrm{CfC} 4$ & 38.3 & 13.4 & 3.3 & -18.6 & 8.1 & & \\
\hline
\end{tabular}

Table 2

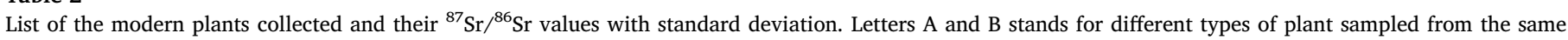
location.

\begin{tabular}{|c|c|c|c|c|c|c|}
\hline & \multirow[t]{2}{*}{ Geological setting } & \multirow[t]{2}{*}{ Sample name } & \multicolumn{2}{|c|}{ Decimal degrees } & \multirow[t]{2}{*}{${ }^{87} \mathrm{Sr} /{ }^{86} \mathrm{Sr}$} & \multirow[t]{2}{*}{ $\pm 2 \sigma$} \\
\hline & & & Latitude, $\mathrm{N}$ & Longitude, W & & \\
\hline \multirow[t]{3}{*}{ From site } & Diorites and gabbro & DG1A & 38.440500 & 7.547583 & 0.714222 & 0.000021 \\
\hline & Diorites and gabbro & DG1B & 38.440500 & 7.547583 & 0.713968 & 0.000029 \\
\hline & Diorites and gabbro & DG2 & 38.453889 & 7.534389 & 0.714016 & 0.000023 \\
\hline \multirow[t]{11}{*}{ Plants nearby enclosure } & Granodiorite & G1A & 38.420833 & 7.481194 & 0.713869 & 0.000023 \\
\hline & Granodiorite & G1B & 38.420833 & 7.481194 & 0.718442 & 0.000023 \\
\hline & Granodiorite & G2 & 38.451639 & 7.400500 & 0.713690 & 0.000024 \\
\hline & Schist & S1 & 38.377139 & 7.556694 & 0.713837 & 0.000020 \\
\hline & Schist & S2 & 38.445333 & 7.377556 & 0.715475 & 0.000021 \\
\hline & Schist & S3 & 38.474694 & 7.463083 & 0.716809 & 0.000024 \\
\hline & Schist & S4 & 38.498333 & 7.608250 & 0.711465 & 0.000023 \\
\hline & Schist & S5 & 38.457250 & 7.678722 & 0.715685 & 0.000023 \\
\hline & Gneissic granodiorite & Gn1 & 38.479083 & 7.628389 & 0.711885 & 0.000023 \\
\hline & Gneissic tonalites & $\mathrm{Gn} 2$ & 38.475944 & 7.708139 & 0.712124 & 0.000020 \\
\hline & Mixture of sandstones, clay \& limestone & M1 & 38.506500 & 7.586222 & 0.713475 & 0.000020 \\
\hline
\end{tabular}




\section{Results \& discussion}

\subsection{Preservation of collagen}

Quality control parameters were checked to ensure if bones had sufficient amounts of collagen and acceptable in vivo carbon and nitrogen elemental and isotopic signals. These parameters include a collagen yield of $1 \%$ or above, a C/N (atomic) ratio of between 2.9 and 3.6, and carbon and nitrogen weight percentage (for bone collagen the ideal ranges of $\% \mathrm{C}$ is ca. $38.8 \pm 8.8$ and for $\% \mathrm{~N}$ is approximately $10-16 \%$ ) (DeNiro, 1985; Ambrose, 1990). It should be noted that these ranges are only approximate indicators of collagen preservation and can vary between each study.

All of 35 samples analysed had a collagen yield of $>1 \%$. All other collagen quality parameters were also met (see Table 1 for further information), except for the samples of 3 dogs (CfC1, CfC2, and CfC3) and 1 goat/sheep (O/cC2), which had low carbon (from 0.9 to $25.2 \%$ ) and nitrogen (from 3.8 to $8.9 \%$ ) weight percentage, so they were excluded from further analysis as their isotopic composition may have been altered during burial. Another sample (BtC2, cattle) had a lower nitrogen content (10.9\%) and unexpected $\delta^{13} \mathrm{C}$ and $\delta^{15} \mathrm{~N}$ values of $-14.7 \%$ and $8.6 \%$, and it was deemed as an outlier due to probable degradation of the sample. In total, around $14 \%$ of the samples analysed presented values of collagen yield and $\mathrm{C} / \mathrm{N}$ ratio outside of the range acceptable for preserved collagen and were therefore not used for further discussion.

\subsection{Dietary patterns}

Values of $\delta^{13} \mathrm{C}$ and $\delta^{15} \mathrm{~N}$ recorded in bones from faunal specimens are presented in Table 1. Overall $\delta^{13} \mathrm{C}$ values (see Fig. 4) for the Perdigões fauna vary from $-21.9 \%$ (O. cuniculus) to $-18.6 \%$ (Canis fa-

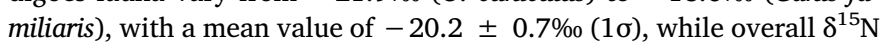
values (see Fig. 5) range from 3.3\% (Ovis/Capra) to 9.8\% (Canis familiaris), with a mean value of $5.9 \pm 1.4 \%$ (1б). The average values for the wild animals were calculated excluding the rabbit (OcC1) because of its $\delta^{13} \mathrm{C}$ low value, probably due to a canopy effect (Bonafini et al., 2013), which is not observed for the majority of the other samples. This rabbit was probably feeding in a dense forest area, where the $\mathrm{C}_{3}$ plants on the ground present $\delta^{13} \mathrm{C}$ values lower than those growing in more open fields. The horse values were also not used for the calculations of the average values because it is not certain whether they should be considered wild or domesticated.

Based on these data, the sampled fauna obtained the majority of their protein from a food-web based on $\mathrm{C}_{3}$ plant resources. This is in agreement with data from other contemporaneous sites in Europe as the relatively narrow variations in ${ }^{13} \mathrm{C} /{ }^{12} \mathrm{C}$ ratios at the beginning of the food chain can be attributed to the minimal availability of $\mathrm{C}_{4}$ type plants in prehistoric Europe (Laffranchi et al., 2016).

At Perdigões, bone carbon and nitrogen isotopic values of wild animals from Late Neolithic (mean value of $-20.0 \pm 0.7 \%$ in $\delta^{13} \mathrm{C}$ and $6.6 \pm 0.8 \%$ in $\delta^{15} \mathrm{~N}$ ) are similar for carbon but display a difference for nitrogen in comparison to wild fauna of Chalcolithic period (mean value of $-19.8 \pm 0.3 \%$ in $\delta^{13} \mathrm{C}$ and $4.5 \pm 0.2 \%$ in $\left.\delta^{15} \mathrm{~N}\right)$. While the domestic animals had average values of $20.1 \pm 0.5 \%$ in $\delta^{13} \mathrm{C}$ and $5.8 \pm 1.6 \%$ in $\delta^{15} \mathrm{~N}$ during the Neolithic and $20.0 \pm 0.6 \%$ in $\delta^{13} \mathrm{C}$ and $6.5 \pm 1.2 \%$ in $\delta^{15} \mathrm{~N}$ in Chalcolithic period, reflecting similar diets and animal management practices over the time. Though, the nitrogen values are slightly higher in the Chalcolithic domestic animals.

Neolithic and Chalcolithic samples of wild fauna $(n=7$, red deer and auroch) exhibit roughly similar $\delta^{13} \mathrm{C}$ and $\delta^{15} \mathrm{~N}$ values $(-19.9 \pm 0.5 \%$ and $5.7 \pm 1.3 \%$ respectively) to those of domestic fauna $(\mathrm{n}=22)$ with a mean $\delta^{13} \mathrm{C}=-20.2 \pm 0.4 \%$ and $\delta^{15} \mathrm{~N}=5.7 \pm 1.1 \%$. The larger variation in $\delta^{15} \mathrm{~N}$ values in both domestic and wild animals might be due to browsing and grazing of ruminant species (sheep/goat, red deer, cattle) in diverse habitats with distinct isotopic signals, either because of differences in herding and feeding practices and/or different provenance of the animals. In the Neolithic period sheep/goat nitrogen isotope values range from 3.3 to $5.7 \%$ in $\delta^{15} \mathrm{~N}$, while cattle shows values from 5.8 to $6.9 \%$. These differences may be due to humans' land management (species were kept on different type of grassland), or slight differences in sheep/goat and cattle husbandry strategies - herbivorous natural preference being replaced by the food provided by pastoralists. It should be taken into consideration that animals of the same species fed with similar diet can have variations in their $\delta^{13} \mathrm{C}$ values of up to $2 \%$ (De Niro and Epstein, 1978), and the observed slight variations between groups (interpopulations) in $\delta^{13} \mathrm{C}$ values might be due to this shift.

The Chalcolithic horse sample, EsC1, had a lower nitrogen isotopic value and a lower carbon isotope value in comparison to other domestic species. The $\delta^{13} \mathrm{C}$ ratio of the sample is closer to that of the rabbit, reflecting browsing in forested environments, thus suggesting it was probably wild. The Neolithic horse samples, EcN1 and EcN2, present carbon isotope values similar to that of the other domesticated animals. The analysis of a large number of Equus sp. samples is necessary to draw more definite conclusions regarding their wild/domestic status, however.

The pigs (SN1 to SN4 and SC1 to SC4) present one of the largest $\delta^{13} \mathrm{C}$ and $\delta^{15} \mathrm{~N}$ ranges of the samples analysed, which is likely due to their omnivorous feeding habits. In case they were domestic animals, they were probably fed human food waste, which likely contained variable amounts of animal protein, which can account for such wide range of $\delta^{15} \mathrm{~N}$ values. The dogs analysed (CfN1 and CfC4) have the highest values on the $\delta^{15} \mathrm{~N}$ scale, in comparison to the herbivores and omnivores, which is understandable due to their carnivorous nature. The $\delta^{13} \mathrm{C}$ values of dogs is less negative than that of the omnivorous pigs which may be the result of higher meat consumption (or so-called "carnivore effect") on the basis that they were likely provisioned with more protein scraps from human meals due to their close relationship. The dog from the Late Neolithic period has a higher nitrogen isotope value and lower carbon isotope value than the Chalcolithic dog which might be due to a reduced consumption of meat products and increased consumption of cultivated crops during the Chalcolithic, or it might be due to environmental factors - areas with wetter soils can have depleted ${ }^{13} \mathrm{C}$ values while high aridity levels and manuring can lead to enriched nitrogen environments with higher $\delta^{15} \mathrm{~N}$ values (Britton et al., 2008; Bogaard et al., 2007). Paleoenvironmental data suggests that the Chalcolithic period was more humid (Section 2.2) but, taking into consideration the carbon and nitrogen isotope values for the wild and domesticated fauna, there is no indication of soil manuring.

Overall, comparing Perdigões domestic fauna from the Neolithic and Chalcolithic periods, only slight differences appear in bone carbon and nitrogen isotopic values, showing more or less traditional husbandry practices of prehistoric pastoralists with a semi-free to free range management of the herds. The slight shifts in $\delta^{13} \mathrm{C}$ and $\delta^{15} \mathrm{~N}$ values (Figs. 4 and 5) might be due to environmental factors (slight variations in the $\delta^{13} \mathrm{C}$ of atmospheric $\mathrm{CO}_{2}$, temperature and humidity levels), animal behavioural factors (food selection, choice of plants with most nourishments available) or due to pastoralist influence (choice of feeding crops and animal herding strategies). Similar differences in animal isotopic values were observed in studies done by Waterman et al. (2016) and Guiry et al. (2016a, 2016b) in contemporaneous sites from Portugal. As seen in Fig. 6a, all the sites mentioned in these studies are situated in the coastal area of the Estremadura region, while Perdigões is an inland site. Although the sites are geographically distant, they all exhibit very similar dietary patterns for their fauna, indicating that the animal management practices were probably very similar during the Neolithic/Chalcolithic period, despite the differences in soil (Fig. 2) and climatic conditions. 

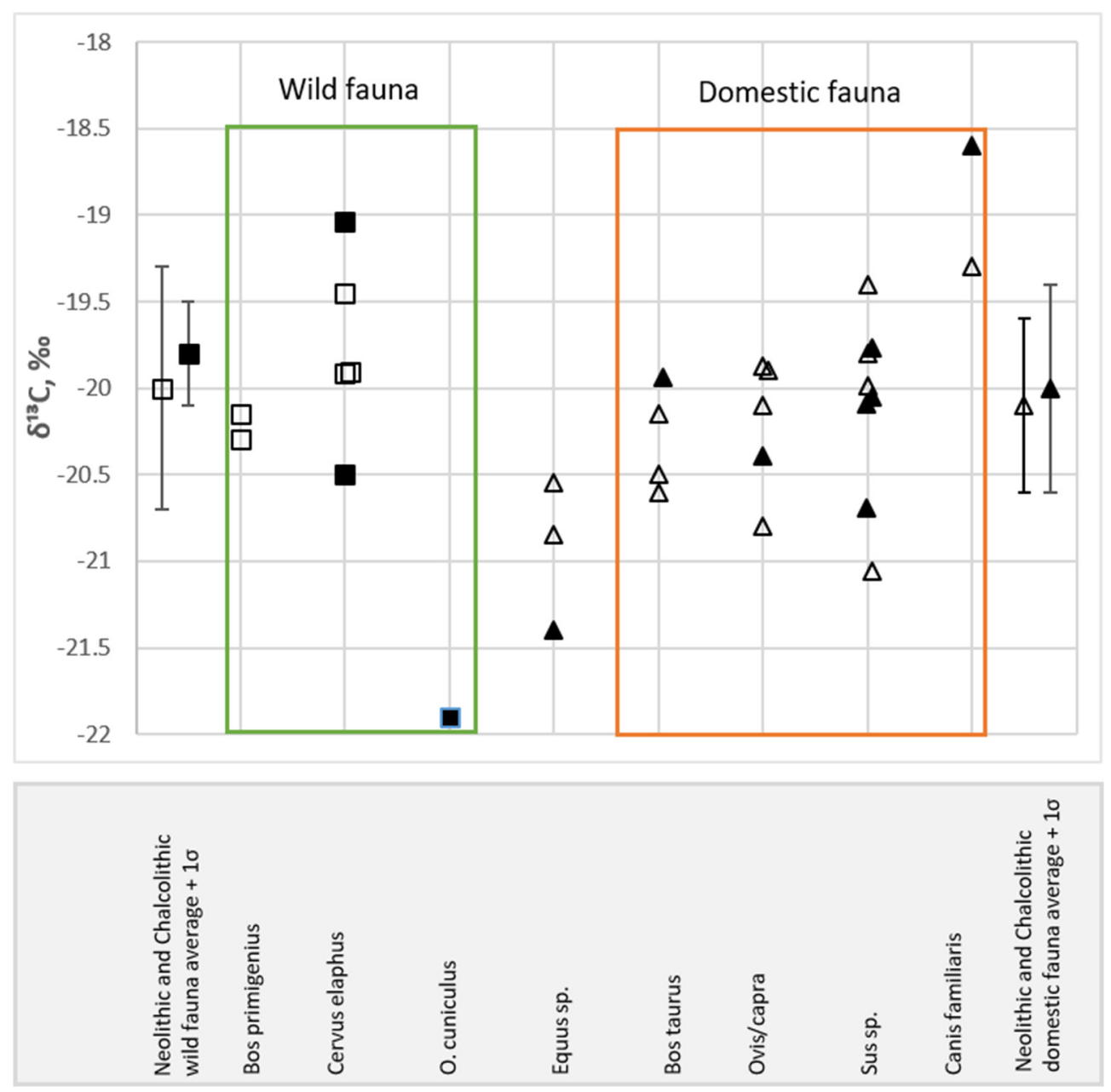

Fig. 4. $\delta^{13} \mathrm{C}$ values recorded in the faunal remains buried in Perdigões. Open symbol for Late Neolithic, filled symbol for Chalcolithic period. Calculated average of wild fauna did not include rabbit value.

\subsection{Mobility}

The ${ }^{87} \mathrm{Sr} /{ }^{86} \mathrm{Sr}$ of modern plants collected nearby the site is provided in Table 2. Samples were collected from 5 different geological units: 3 were taken directly from the site, a gabbro-diorite geological setting, 3 from granodiorite, 5 from schist one sample came from a mixture of sandstones, limestones and clays and 2 from a gneissic setting. The strontium isotope values of modern plants ranged from 0.711465 to 0.718442 , with the lowest isotope ratio belonging to a plant sample coming from a schist geological setting, while the plant sample yielding the highest strontium isotope value came from a granodioritic unit. Plants coming from granodioritic or schist geological setting displayed a wide range of values, while plants from the gabbro-dioritic unit close to the site had a narrower range. This wide range of values within a short geographical distance from the site (between 5 and $10 \mathrm{~km}$ ) was expected, because of the complexity of the geological landscape (Fig. 3) in the surroundings of the Perdigões site (Paleozoic schist and granite rocks, characterizing the region and giving higher ${ }^{87} \mathrm{Sr} /{ }^{86} \mathrm{Sr}$ ratios).

Following the suggestion by Price et al. (2002), the local bioavailable range of Perdigões was obtained by calculating the mean value \pm 2 standard deviations ( $\sigma$ ) of plants obtained directly from the site, and range from 0.713798 to 0.714339 . This is also consistent with the range obtained for the granodiorite area of the valley that surrounds the gabbro-diorite rocks where Perdigões is located.

The range of strontium isotope data obtained from faunal samples involved in this study is extensive, from 0.711062 to 0.717240 (Table 1). The average ${ }^{87} \mathrm{Sr} /{ }^{86} \mathrm{Sr}$ values in animal enamel from the
Neolithic and Chalcolithic periods are, respectively, $0.714171 \pm 0.001634(1 \sigma)$ and, $0.714885 \pm 0.001833(1 \sigma)$. According to the local ${ }^{87} \mathrm{Sr} /{ }^{86} \mathrm{Sr}$ baseline previously defined, only one sheep/goat individual $(\mathrm{O} / \mathrm{cN} 3)$ showed $a{ }^{87} \mathrm{Sr} /{ }^{86} \mathrm{Sr}$ value within the determined local bioavailable strontium range, whereas one dog sample (CfC3) displayed a strontium isotope value (0.71106) much lower than the determined bioavailable range, and more typical of other geological areas (Figs. 7 and 8).

Most of the other analysed samples have ${ }^{87} \mathrm{Sr} /{ }^{86} \mathrm{Sr}$ values like those found in the plants collected from the schist area surrounding what was defined as the local scale of the settlement network for Perdigões (Figs. 3 and 7). It is assumed by some authors that during the NeolithicChalcolithic domesticated animals were kept in fields surrounding the archaeological sites (Waterman et al., 2013). However, at Perdigões they seem to have ${ }^{87} \mathrm{Sr} /{ }^{86} \mathrm{Sr}$ isotope values that do not match the surroundings of the enclosure, but rather the surroundings of the Ribeira do Álamo valley, which constitutes the core area of the local settlement network. It is also interesting to note the behaviour of the domesticated pigs, which, in general, are not very mobile and tend to be kept close to the houses for use in refuse management and due to their need for shade and wallow (McClure et al., 2006). Due to the large number of suids found at the site, they were thought to be domesticated, even considering the large range of $\delta^{13} \mathrm{C}$ and $\delta^{15} \mathrm{~N}$ collagen values they showed (Table 1, Figs. 4 and 5), and which were assumed to arise from their omnivorous nature. However, looking at the ${ }^{87} \mathrm{Sr} /{ }^{86} \mathrm{Sr}$ results for the animals, it seems that it is more likely that the Sus sampled form Perdigões were either wild pigs and/or they had not been raised at the 

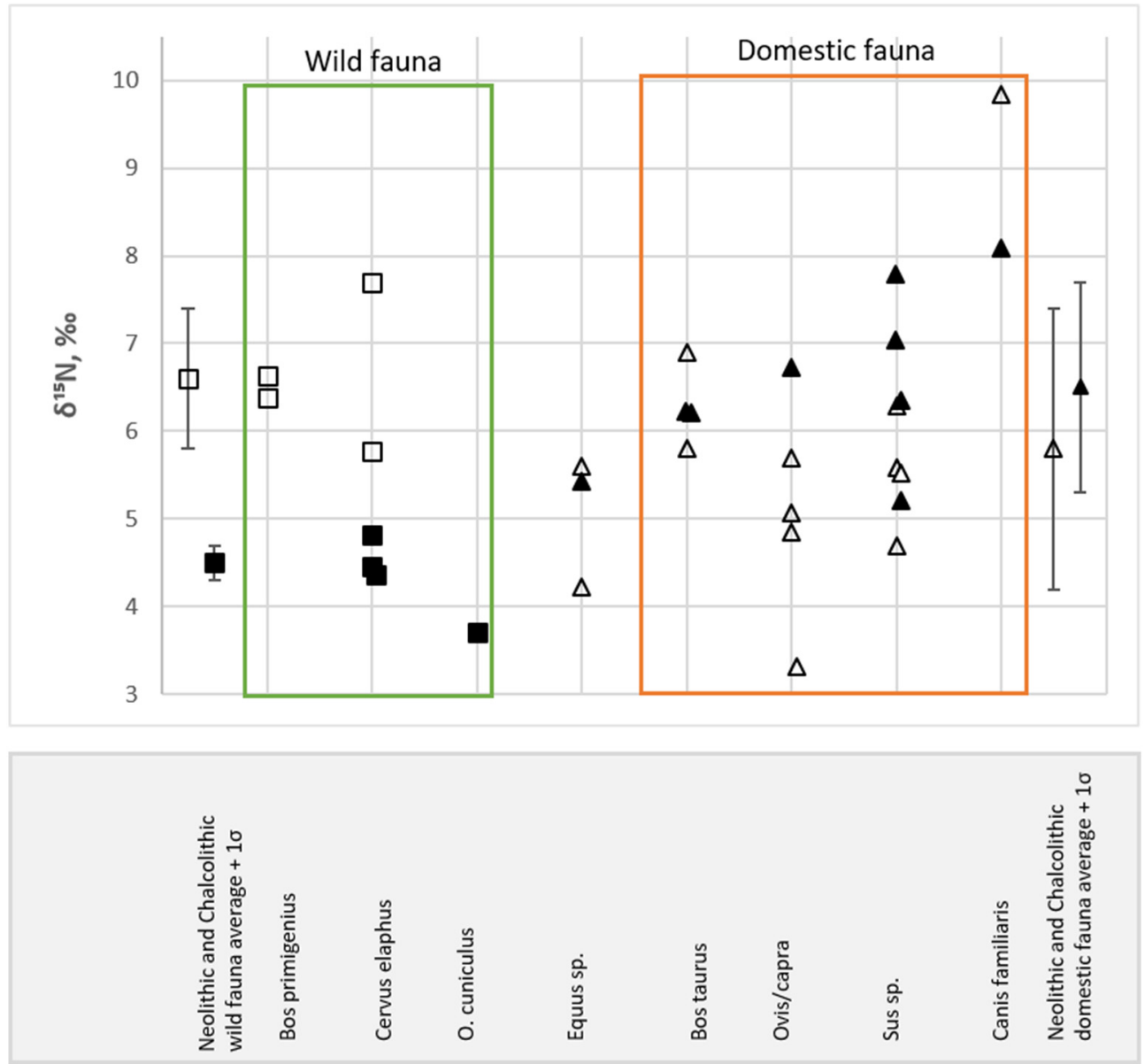

Fig. 5. $\delta^{15} \mathrm{~N}$ values recorded in the faunal remains buried in Perdigões. Open symbol for Late Neolithic, filled symbol for Chalcolithic period. Calculated average of wild fauna did not include rabbit value.

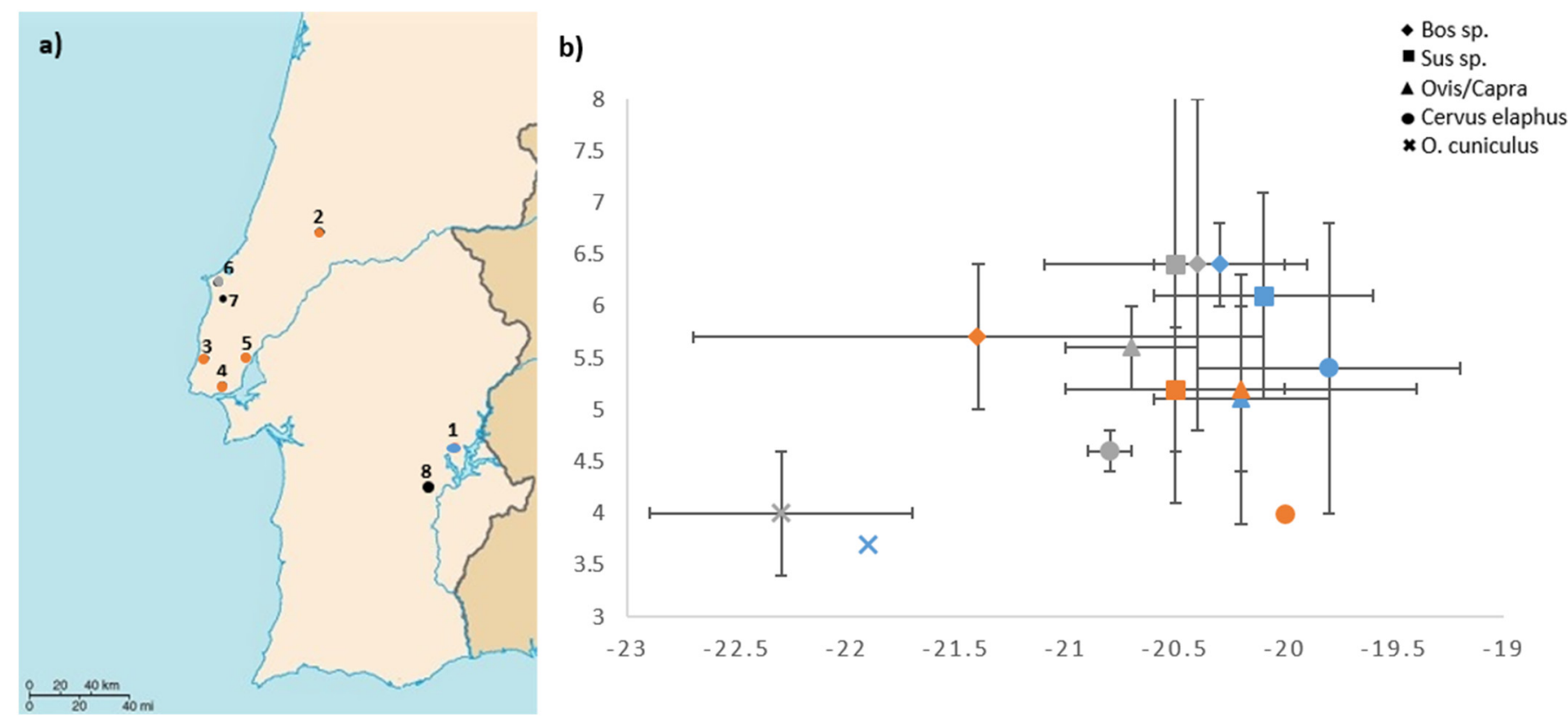

Fig. 6. a) Map of the location of Perdigões (1) and of the sites described in Guiry et al. (2016a, 2016b) (Cadaval (2), Carrascal and Leceia (4), Moita da Ladra (5) and Penedo do Lexim (3)) and Waterman et al. (2016) (Feteira II, Paimogo I, Lapa da Rainha II (6), Bolores, Borracheira, Cabeço da Arruda, Cova da Moura (7)). The location of Roman/late Antiquity site of Monte da Cegonha (8) is also presented; b) $\delta^{13} \mathrm{C}$ and $\delta^{15} \mathrm{~N}$ isotope values of bone collagen showing mean values $\pm 1 \sigma$ of fauna from Perdigões in blue, sites mentioned in Guiry et al. (2016a, 2016b) in orange and sites mentioned in Waterman et al. (2016) in grey color. (For interpretation of the references to color in this figure legend, the reader is referred to the web version of this article.) 


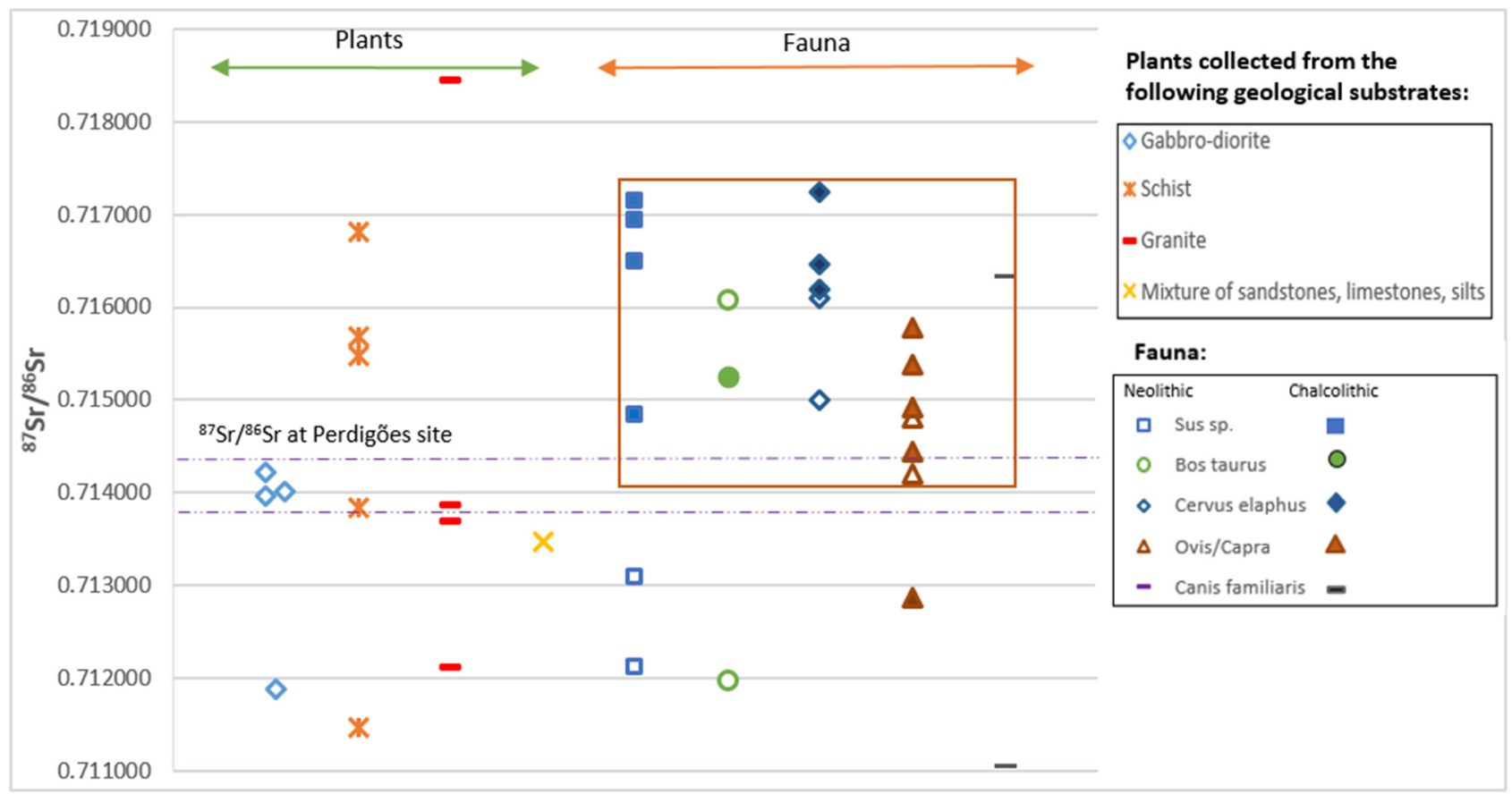

Fig. 7. Strontium isotope values of modern plants and tooth enamel of archaeological fauna samples from the site of Perdigões.

site and were thus brought there.

One dog sample (CfC3) displayed a relatively low strontium isotope value, perhaps typical of other geological areas, while another one points to the area of the valley, whereas only one individual $(\mathrm{O} / \mathrm{cN} 3$, sheep/goat) of the fauna analysed had a ${ }^{87} \mathrm{Sr} /{ }^{86} \mathrm{Sr}$ had a value within the determined local bioavailable strontium range (Fig. 7).

Since these samples represent only a small percentage of the excavated faunal remains, we can only cautiously comment on each species' mobility patterns individually. The range of strontium isotope values in pigs is extremely wide $(0.712-0.717)$ while that of the red deer is narrower (0.715-0.717), with cattle and sheep/goat exhibiting quite spread out values too. Within the sheep/goat specimens, there is a restricted range of values from 0.714 to 0.716 , with only one individual deviating from this pattern and showing a lower value of about 0.712 . This could indicate very different mobility patterns for these domestic animals as different species can occupy different regions with varying home ranges (Bentley, 2006). This is in part consistent with the diversified geology surrounding the valley where the site of Perdigões is located, making ${ }^{87} \mathrm{Sr} /{ }^{86} \mathrm{Sr}$ values vary widely.

A significant percentage of the analysed fauna could have been raised around the local settlement network (that is to say, outside the gabbro-diorite, Perdigões site, and granodiorite areas where the great majority of megalithic monuments and settlements are located). With $17 \%$ of the fauna samples having much lower ${ }^{87} \mathrm{Sr} /{ }^{86} \mathrm{Sr}$ isotope values

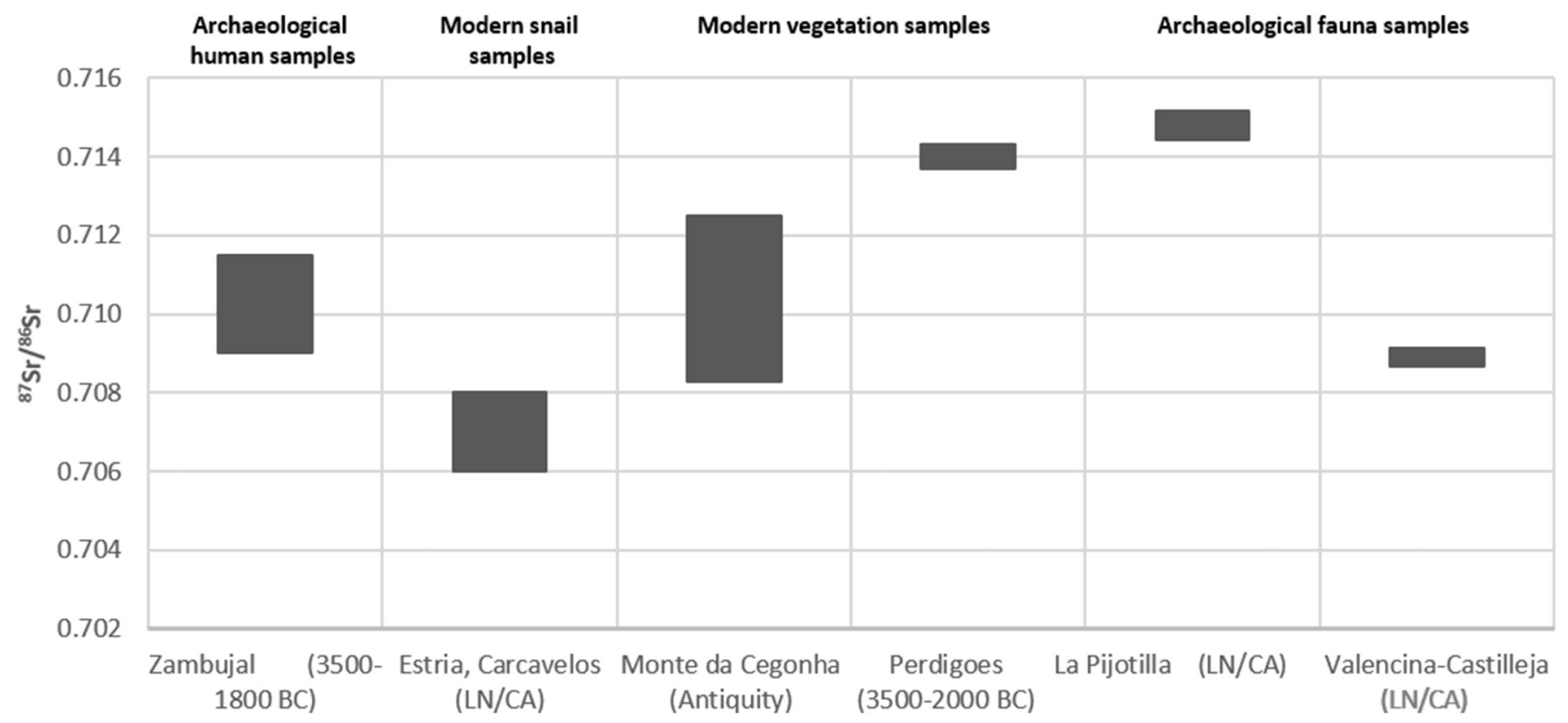

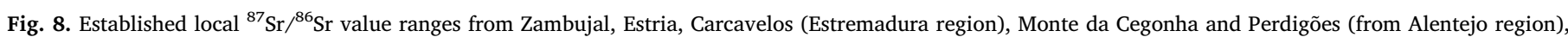

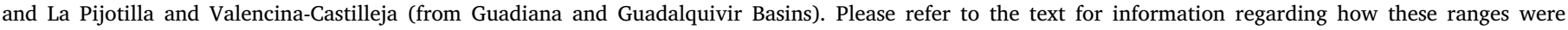
calculated in the different sites. 
then the local established baseline. To provide a larger, or regional, perspective we compared the Perdigões faunal strontium isotope data to strontium isotope values from other studies in Portugal and Spain (Fig. 8). Two studies were performed in the Estremadura region by Waterman et al. (2013) and Hillier et al. (2010) on the site of Zambujal, a Chalcolithic fortified burial settlement, and on Estria and Carcavelos, which are Late Neolithic and Chalcolithic burial sites respectively. Local strontium isotopic values of Zambujal exhibited a range of 0.7090 to 0.7115 (defined by a mean value \pm 2 s.d. of the sampled humans, excluding the outliers), while Estria and Carcavelos were calculated using modern land snails and showed a lower ${ }^{87} \mathrm{Sr} /{ }^{86} \mathrm{Sr}$ isotope range of 0.706 to 0.708 , even though both sites are $<30 \mathrm{~km}$ away from Zambujal. A similar outcome of having quite different ${ }^{87} \mathrm{Sr} /{ }^{86} \mathrm{Sr}$ values close by can be seen in the Alentejo region, if we compare Perdigões and Monte de Cegonha strontium isotope values. Monte da Cegonha is a Late Antiquity settlement located in Alentejo region not far from Perdigões (Fig. 6a(8)), and similarly to our study, Saragoça et al. (2016) used modern vegetation samples from nearby the site to establish the bioavailable strontium signal of 0.7083 to 0.7125 . Lastly, Díaz-Zorita Bonilla (2013) reported strontium isotope values from archaeological fauna at two Late Neolithic and Copper Age sites from Guadiana and Guadalquivir basin in the Spanish territory. La Pijotilla $(n=4)$ and Valencina-Castilleja $(\mathrm{n}=7)$ with bioavailable ranges from 0.7141 to 0.7151 and 0.7086 to 0.7091 , respectively. One evident reason for the widely varying ${ }^{87} \mathrm{Sr} /{ }^{86} \mathrm{Sr}$ values from site to site can be attributed to a diverse and complex geological setting of the Iberian Peninsula.

For example, samples of Sus sp. (SN1), Bos taurus (BtN2) and Canis familiaris (CfC2) with the lowest measured signal from Perdigões site might come from somewhere close to Monte da Cegonha or a place with a similar geological substrate, because ${ }^{87} \mathrm{Sr} /{ }^{86} \mathrm{Sr}$ values from these three Perdigões samples are closer to Cegonha's range. Results from studies of sites in Portuguese Estremadura, in Guadiana and Guadalquivir basins and in Alentejo region, clearly demonstrate how variable the strontium data can be even in relatively close places within each region. This means that while the non-local fauna from Perdigões could have originated from a different geological region, but perhaps not requiring movement over long distances from the archaeological site, the data presented here suggests their origin was not in the immediate surroundings or from the Ribeira do Álamo valley.

Because of sparse numbers of analysed animals between periods (especially dating to the Neolithic period) no definite conclusions can be drawn regarding their mobility patterns. However, what can be said with the available results is that the large range in strontium isotope values presented by the animal samples could be due to variations in the bioavailable strontium around the local settlement network (detected by the plant strontium data), and on diverse foraging behaviour of ovicaprids, suids and bovids. However, taking into consideration the nature of the archaeological site (astronomic orientations, being a vantage point to the highly monumentalized landscape of the Álamo valley, intense funerary practices - manipulation of human remains and several depositional practices - significant interaction and concentrations of exotic materials associated to social emulation practices Valera, 2017) that point to a meeting place of highly symbolic reference, the observed differences can also arise from different provenances of the animals, which could have been brought from other nearby locations (outside the Ribeira do Álamo valley) due to human mobility, something that the results obtained for the Sus strongly suggests.

Animals from the Neolithic period, such as sheep/goat, pig and red deer, all have similar ranges between species, while cattle exhibit a larger strontium isotope difference (0.711 and 0.716$)$, which might indicate either totally different places of birth or herding origins. While the animals from the Chalcolithic period exhibit a wider range in strontium isotope values ( 0.711062 to 0.717240$)$, chalcolithic pig and sheep/goat samples each had one animal that was significantly divergent from all the others in their respective groups, which might be due to animal movement or herding practices. Also, even though our sample might not be representative of the site's total faunal assemblage, one general trend between Neolithic and Chalcolithic fauna can be seen. Fauna from the Neolithic period have lower strontium isotope values in comparison to those from the Chalcolithic period. This might be related to animal management practices, for instance change of herding place - towards north-west of Reguengos de Monsaraz during Neolithic and north-east during Chalcolithic, according to the obtained plant values (refer to Fig. 3). The wider range values can also be related to the increase in interaction, such that Chalcolithic period Perdigões was involved in a much wider interaction network, which can be observed by the amount of exotic materials that are present at the funerary contexts at the site in this period (Valera, 2017). This study supports the view that the fauna analysed alongside humans, and used for further diet and mobility interpretation, must be contemporary because there are slight differences between periods.

Dietary results of analysed fauna were cross-referenced with the strontium analysed ones, as some samples had data from both analyses done. Two sheep/goat samples $(\mathrm{O} / \mathrm{cN} 2$ and $\mathrm{O} / \mathrm{cN} 3)$ from the Neolithic period had large differences in nitrogen isotope values $-5.1 \%$ and $3.3 \%$ respectively. This difference could be due to the choice of plant or plant's segment being consumed (different plant parts have different amounts of nitrogen being allocated throughout the plant (Szpak, 2014)), and not so much from the different geological substrates they come from, if we consider their slight differences in strontium isotope values.

The two red deer samples (CeN1 and CeN2), also from the Late Neolithic period, have values in $\delta^{13} \mathrm{C}$ of $-20.5 \%$ and $-19.0 \%$; $\delta^{15} \mathrm{~N}$ of $5.8 \% 0$ and $7.7 \% 0$ and ${ }^{87} \mathrm{Sr} /{ }^{86} \mathrm{Sr}$ of 0.715 and 0.716 correspondingly. These differences between isotope values might reflect that deer have come from different ecological niches (meaning two isotopically different landscapes). Samples of pig (SN1 and SN2) had similar values in their carbon and strontium but differences in nitrogen. Their values of nitrogen were closer to those of red deer, which again attests to the possibility of these suids being a wild species. While the two cattle samples (BtN2 and BtC1) show similar isotope values in carbon and nitrogen but have large differences in the strontium isotope values. Probably these animals have been fed with similar crops but raised in different places (animals being herded in north-west during Neolithic and north-east during Chalcolithic).

\section{Conclusions}

In this article, we presented carbon, nitrogen and strontium isotope analyses of fauna from the Perdigões ditched enclosure from the Late Neolithic through Chalcolithic periods to identify patterns of animal subsistence, mobility, their management practices and to establish a local isotope baseline. Due to limited sample sizes of each species, the results should be interpreted with caution. From other studies it is known that the consumption of hunted animals was initially important at Perdigões, while during the life span of the site most animals at the already studied contexts were domestic. The $\delta^{13} \mathrm{C}$ and $\delta^{15} \mathrm{~N}$ values of the animal bone collagen reflect patterns that conform to general expectations - those animals subsisted on terrestrial based $\mathrm{C}_{3}$ plants resources with values between -19.5 and $-21 \%$ in $\delta^{13} \mathrm{C}$ of bone collagen with no significant changes in subsistence patterns through time.

The analysis of plants from within and around the Perdigões site suggests a large variability in the strontium isotope values in the area, which is justifiable given the geological complexity of the local settlement network surroundings (the granodiorite area of Ribeira do Álamo valley). Strontium isotope analysis of the archaeological fauna showed that most animals did not come directly from the site or its immediate surroundings in the Alámo valley but could have browsed and grazed not further than about a $10-\mathrm{km}$ radius from the site. However, due to the large variability of strontium isotope values within a $200-\mathrm{km}$ radius (Fig. 8) of Perdigões, some of the studied fauna could have been 
brought to the site by humans from further away.

The obtained faunal isotope dataset will be further used as a baseline to compare and interpret human isotope values from the site of Perdigões. Also, future research will focus on expanding sample sizes for faunal domesticates and, especially, wild species to ascertain the differences and changes between these two groups. Our results also highlight the importance of analysing humans with contemporary fauna, which is the ongoing step of the project.

\section{Acknowledgements}

This study is part of the research project "Mobinter - Mobility and interaction in South Portugal Recent Prehistory: the role of aggregation centres" (PTDC/EPH-ARQ/0798/2014) funded by the Portuguese Science and Technology Foundation (FCT). Alison Harris, Kevin Smith, Alicia Morry and Dr. Rebecca Lam are thanked for the preparation and analysis of samples at the MAAS and CREAIT laboratories at Memorial University.

\section{References}

Al-Shorman, A., El-Khouri, L., 2011. Strontium isotope analysis of human tooth enamel from Barsinia: a late antiquity site in northern Jordan. Archaeol. Anthropol. Sci. 3 263-269.

Ambrose, S.H., 1990. Preparation and characterization of bone and tooth collagen for isotopic analysis. J. Archaeol. Sci. 17 (4), 431-451.

Ambrose, S.H., 1993. Isotopic analysis of paleodiets: methodological and interpretive considerations. In: Sanford, M.K. (Ed.), Elemental and Isotopic Analyses: Understanding Diet and Disease in Past Populations. Gordon and Breach Science Publishers, New York, pp. 59-130.

Antunes, A., et al., 2010. New petrographic, geochemical and geochronological data for the Reguengos de Monsaraz pluton (Ossa Morena Zone, SW Iberian Massif, Portugal). Estud. Geol. 66 (1), 25-34.

Bentley, A.R., 2006. Strontium isotopes from the earth to the archaeological skeleton: a review. J. Archaeol. Method Theory 13 (3), 135-187.

Bocherens, H., Drucker, D., 2003. Trophic level isotopic enrichment of carbon and nitrogen in bone collagen: case studies from recent and ancient terrestrial ecosystems. Int. J. Osteoarchaeol. 13 (1-2), 46-53.

Bogaard, A., Heaton, T.H.E., Poulton, P., Merbach, I., 2007. The impact of manuring on nitrogen isotope ratios in cereals: archaeological implications for reconstruction of diet and crop management practices. J. Archaeol. Sci. 34 (3), 335-343.

Bonafini, M., Pellegrini, M., Ditchfield, P., Pollard, A., 2013. Investigation of the 'canopy effect' in the isotope ecology of temperate woodlands. J. Archaeol. Sci. 40, 3926-3935. http://dx.doi.org/10.1016/j.jas.2013.03.028.

Britton, K., Müldner, G., Bell, M., 2008. Stable isotope evidence for salt-marsh grazing in the Bronze Age Severn Estuary, UK: implications for palaeodietary analysis at coastal sites. J. Archaeol. Sci. 35 (8), 2111-2118.

Cabaço, N., 2010. Restos faunísticos em contexto do Neolítico final do Sector Q do recinto dos Perdigões (Reguengos de Monsaraz). In: Apontamentos de Arqueologia e Património. 5. pp. 27-30

Cabaço, N., 2012. Restos faunísticos em contexto funerário nos Perdigões, Reguengos de Monsaraz (Sepulcros 1 e 2). Actas das IV Jornadas de Jovens em Investigação Arqueológica - JIA 2011: Faro, 11 a 14 de Maio de 2011. Promontória Monográfica. 16(1). pp. 259-267.

Carvalhosa, A.; Zbyszewski, G., (1991). Noticia explicativa da Folha 40-B (Reguengos de Monsaraz) da Carta geologica de Portugal na escala de 1:50 000. Lisboa: Servicos geologicos de Portugal.

Copeland, S.R., et al., 2008. Strontium isotope ratios $\left({ }^{87} \mathrm{Sr} /{ }^{86} \mathrm{Sr}\right)$ of tooth enamel: a comparison of solution and laser ablation multicollector inductively coupled plasma mass spectrometry methods. Rapid Commun. Mass Spectrom. 22 (20), 3187-3194.

Cordeiro da Costa, C.M., 2013. Tafonomia em contexto pré-histórico: a zooarqueologia como recurso para a compreensão das "estruturas em negativo" da pré-história recente. Universidade do Algarve, Faro.

Costa, C., 2010. Os restos restos faunísticos de animais vertebrados do Sector I dos Perdigões (fossas e fossos 3 e 4). In: Apontamentos de Arqueologia e Patrimonio. vol. 6. pp. 53-74.

Danielsen, R., Mendes, P.M., 2013. Pollen analysis of Late Neolithic ditch deposits from the Perdigoes archaeological site. In: Apontamentos de Arqueologia e Património. vol. 9. pp. 13-20.

De Niro, M.J., Epstein, S., 1978. Influence of diet on the distribution of carbon isotopes in animals. Geochim. Cosmochim. Acta 42, 495-506.

DeNiro, M.J., 1985. Postmortem preservation and alteration of in vivo bone collagen isotope ratios in relation to palaeodietary reconstruction. Nature 317, 806-809.

Díaz-Zorita Bonilla, M., 2013. The Copper Age in South-west Spain: A Bioarchaeological Approach to Prehistoric Social Organisation. Durham University, Durham.

Fontanals-Coll, M., Diaz-Zorita Bonilla, M., Subira, M.E., 2016. A palaeodietary study of stable isotope analysis from a high-status burial in the copper age: the Montelirio megalithic structure at Valencina de la Concepción-Castilleja de Guzmán, Spain. Int. J. Osteoarchaeol. 26 (3), 447-459.

Guiry, E.J., 2012. Dogs as analogs in stable isotope-based human paleodietary reconstructions: a review and considerations for future use. J. Archaeol. Method Theory
$19,351-376$.

Guiry, E.J., Hepburn, J.C., Richards, M.P., 2016a. High-resolution serial sampling for nitrogen stable isotope analysis of archaeological mammal teeth. J. Archaeol. Sci. 69, 21-28.

Guiry, E.J., et al., 2016b. The transition to agriculture in south-western Europe: new isotopic insights from Portugal's Atlantic coast. Antiquity 90 (351), 604-616.

Hedges, R.E., Reynard, L.M., 2007. Nitrogen isotopes and the trophic level of humans in archaeology. J. Archaeol. Sci. 34, 1240-1251.

Hillier, M., Boaventura, R., Grimes, V., 2010. Moving Around? Testing Mobility With Strontium Isotopes $\left({ }^{86} \mathrm{Sr} /{ }^{87} \mathrm{Sr}\right)$ in the Late Neolithic of South-Central Portugal. (Silves, s.n.).

Hoppe, K.A., Koch, P.L., Furutani, T.T., 2003. Assessing the preservation of biogenic strontium in fossil bones and tooth enamel. Int. J. Osteoarchaeol. 13, 20-28.

Knipper, C., Peters, D., Meyer, C., Alt, K.W., 2013. Dietary reconstruction in migration period Central Germany: a carbon and nitrogen isotope study. Archaeol. Anthropol. Sci. 5 (1), 17-35.

Laffranchi, Z., et al., 2016. Stable C \& N isotopes in 2100 Year-B.P. human bone collagen indicate rare dietary dominance of C4 plants in NE-Italy. Sci. Rep. 6 (38817), 1-8.

Lee-Thorp, J.A., Sealy, J.A., van der Merwe, N.J., 1989. Stable carbon isotope ratio differences between bone collagen and bone apatite, and their relationship to diet. J. Archaeol. Sci. 16, 585-599.

Longin, R., 1971. New method of collagen extraction for radiocarbon dating. Nature 230, 241-242.

Madgwick, R., Lewis, J., Grimes, V., Guest, P., 2017. On the hoof: exploring the supply of animals to the Roman legionary fortress at Caerleon using strontium $\left({ }^{87} \mathrm{Sr} /{ }^{86} \mathrm{Sr}\right)$ isotope analysis. Archaeol. Anthropol. Sci. 1-13.

Maurer, A.-F., et al., 2012. Bioavailable ${ }^{87} \mathrm{Sr} /{ }^{86} \mathrm{Sr}$ in different environmental samples effects of anthropogenic contamination and implications for isoscapes in past migration studies. Sci. Total Environ. 433 (1), 216-229.

McClure, S.B., Jochim, M.A., Barton, C.M., 2006. Human behavioral ecology, domestic animals, and land use during the transition to agriculture in Valencia, eastern Spain. In: Kennett, D.J., Winterhalder, B. (Eds.), Behavioral Ecology and the Transition to Agriculture, 1st ed. University of California Press, pp. 197-216.

Müldner, G., Britton, K., Ervynck, A., 2014. Inferring animal husbandry strategies in coastal zones through stable isotope analysis: new evidence from the Flemish coastal plain (Belgium, 1st-15th century AD). J. Archaeol. Sci. 41, 322-332.

O'Connell, T., Kneale, C., Tasevska, N., Kuhnle, G., 2012. The diet-body offset in human nitrogen isotopic values: a controlled dietary study. Am. J. Phys. Anthropol. 149 (3), 426-434.

Pate, D.F., 1994. Bone chemistry and paleodiet. J. Archaeol. Method Theory 1 (2), 161-209.

Price, T.D., Burton, J.H., Bentley, R.A., 2002. The characterization of biologically available strontium isotope ratios for the study of prehistoric migration. Archaeometry 44 (1), 117-135.

Reis, S., 1998. A natureza do territorio. In: Povoado Pre-Historico Dos Perdigoes (Reguengos de Monsaraz). Relatorio final dos trabalhos de Salvamento arqueologico. ERA Arqueologia Lda, Lisboa, pp. 10-16.

Reitsema, L.J., Koz1owski, T., Makowiecki, D., 2013. Human-environment interactions in medieval Poland: a perspective from the analysis of faunal stable isotope ratios. J. Archaeol. Sci. 40 (10), 3636-3646.

Saragoça, P., et al., 2016. Stable isotope and multi-analytical investigation of Monte da Cegonha: a late antiquity population in southern Portugal. J. Archaeol. Sci. Rep. 9, $728-774$.

Szpak, P., 2014. Complexities of nitrogen isotope biogeochemistry in plant-soil systems: implications for the study of ancient agricultural and animal management practices. Front. Plant Sci. 5, 1-19.

Valente, M.J., Carvalho, A.F., 2014. Zooarchaeology in the Neolithic and Chalcolithic of southern Portugal. Environ. Archaeol. 19 (3), 226-240.

Valera, A.C., 2012. Mind the Gap: Neolithic and Chalcolithic Enclosures of South Portugal. Enclosing the Neolithic. Recent Studies in Britain and Europe, Issue 2440. pp. 165-183.

Valera, A.C., 2015a. Social Change in the Late 3rd Millenium BC in Portugal: The Twilight of Enclosures. pp. 409-428 (Halle (Saale), s.n.).

Valera, A.C., 2015b. Ídolos falange, cervídeos e equídeos. Dados e problemas a partir dos Perdigões. In: Apontamentos de Arquelogia e Patrimonnio. vol. 10. pp. 7-20.

Valera, A.C., 2017. The 'exogenous' at Perdigões. approaching interaction in the late 4th and 3rd Millennium BC in Southwest Iberia. In: Bartelheim, M., Ramírez, P.B., Kunst, M. (Eds.), Key Resources and Sociocultural Developments in the Iberian Chalcolithic. Tübingen Library Publishing, Tübingen, pp. 201-224.

Valera, A.C., Silva, A.M., Evangelista, L.S., Cunha, C., 2014a. Funerary practices and body manipulation at Neolithic and Chalcolithic Perdigoes ditched enclosures (South Portugal). In: Recent Prehistoric Enclosures and Funerary Practices in Europe, pp. 37-57.

Valera, A.C., Silva, A.M., Márquez Romero, J.E., 2014b. The temporality of Perdigões enclosures: absolute chronology of the structures and social practices. SPAL (23), $11-26$.

van der Merwe, N.J., 1992. Light stable isotopes and the reconstruction of perhistoric diets. Proc. Br. Acad. 77, 247-264.

Waterman, A.J., Peate, D.W., Silva, A.M., Thomas, J.T., 2013. In search of homelands: using strontium isotopes to identify biological markers of mobility in late prehistoric Portugal. J. Archaeol. Sci. 42, 119-127.

Waterman, A.J., Tykot, R.H., Silva, A.M., 2016. Stable isotope analysis of diet-based social differentiation at late prehistoric collective burials in south-western Portugal. Archaeometry 58 (1), 131-151.

Wheeler, J., 2010. Paleoenvironmental assessment of two archaeological sediments from Perdigões, Alentejo Region, Portugal. In: Apontamentos de Arqueologia e Património. vol. 6. pp. 41-45. 